\title{
地下水温と安定同位体比から推定した十勝平野の地下水流動系
}

\author{
池田光良* ·操上広志**.三浦均也**
}

\section{Groundwater Flow System in the Tokachi Plain, Hokkaido, Estimated from Groundwater Temperature and Stable Isotopic Ratio}

\author{
Mitsuyoshi IKEDA*, Hiroshi KURIKAMI** and Kinya MIURA**
}

\begin{abstract}
The characteristics of groundwater flow in the western Tokachi plain is clarified as follows: (a) Groundwater temperature in the piedmont area is less than average and greater than average in the central plain, indicating the recharge and discharge areas, respectively. (b) Groundwater flow velocities estimated from groundwater temperatures are consistent with those from hydraulic analyses. (c) The origin of groundwater in the western Tokachi plain and hot spring from Tokachigawa spa is meteoric. (d) The groundwater flow estimated from the stable isotopic ratios $\delta \mathrm{D}$ and $\delta{ }^{18} \mathrm{O}$ supports the results obtained from groundwater temperature. (e) $\delta \mathrm{D}$ and $\delta{ }^{18} \mathrm{O}$ variations in the Tokachi plain agree with the regional groundwater flow system model, in that deeper aquifers are expected to have lighter isotopic ratios because of the altitude isotope effect, including recharge occurred on Mt. Daisetsuzan or the Hidaka mountains. (f) The eastern geological block of the Tokachi central fault forms the eastern impermeable boundary of the Tokachi artesian basin. (g) Three-dimensional thermal advection-dispersion analysis shows that the Tokachigawa spa is formed as the convergence of groundwater flow in the western Tokachi plain, although the influence of special heat source cannot be ignored.
\end{abstract}

Key Words: Tokachi plain, groundwater flow system, groundwater temperature, stable isotopic ratio, thermal advection-dispersion analysis

* 北海道開発コンサルタント(侏)地質部(

** 北海道大学大学院工学研究科地盤工学講座 ( 


\section{要 旨}

十勝平野西部の地下水流動を検討し、次のことを明らかにした。(a) 地下水温は、山麓 では平均よりも低温、平野の中心部では高温となり、それぞれ涵養域と流出域に対応する と考えられる。(b) 地下水温加推定された地下水流速は、水理学的解析の結果と整合す る。(c) 十勝平野西部の地下水と十勝川温泉水は天水起源である。(d) 穴定同位体比 $\delta \mathrm{D}$ と $\delta^{18} \mathrm{O}$ の分布から推定した地下水流動は、地下水温加の推定と㧍打むね対応している。 (e).十勝平野に押ける $\delta \mathrm{D}$ と $\delta^{18} \mathrm{O}$ の差は広域地下水流動系と対応し、带水層の深度が深い ほど、水の安定同位体比は軽い值を示す。また、大雪山系または日高山脈からの涵養を示 唆する高度効果を示す。(f)十勝中央断層の東側ブロックは十勝地下水盆の東側の不透水 境界的役割を果たしている。(g) 3 次元の熱移流拡散解析から十勝川温泉は、特別な熱源 の影響は無視できないものの、十勝平野西部の地下水流動の収束場と考えることで泉温の 多くを説明できる。

キーワード：十勝平野、地下水流動系、地下水温、安定同位体比、熱移流拡散解析

\section{1. 緒言}

地下水盆中の地下水資源を管理することは、地 下水調査の重要な目的の一つであり、広域調査に 招ける調査資料の不足を補ううえでも地下水温、 地下水中の環境同位体などに代表される環境卜 レーサー1を用いて地下水盆の地下水流動を知る ことは重要な課題となる。本論では十勝平野の深 層地下水を研究対象として、地下水温及び地下水 中の安定同位体比の測定結果を解析することによ り、その流動機構を把握することを試みた。

十勝平野は主として新第三紀鮮新世以降に形成 された堆積盆地である。当初、平野全域に及んで いた堆積盆地はその後縮小し、第四紀更新世後半 には、十勝中央断層 ${ }^{2)}$ を境として東側ブロックが 上昇、西側ブロックが下降して十勝平野は東西に 二分された。現在、十勝川温泉を含む東側は、地 温勾配が $5 \sim 6{ }^{\circ} \mathrm{C} / 100 \mathrm{~m}$ の高温域であり、十勝平 野の西部(帯広盆地ともいう)では $3 \pm 1{ }^{\circ} \mathrm{C} / 100 \mathrm{~m}$ と通常の地温勾配を示す(道立地下資源調查所、 1995）。この東側ブロックの高温の原因として阿 寒の延長である未知の高温岩体の存在が言われて きた。また、十勝平野中心部の深さ $1000 \mathrm{~m}$ 以上か ら取水している“温泉”についても高温岩体の影
響の他、大雪山系から熱水が流入したものではな いかという考えがあった。

一方、平野の末端や盆地の中央部では、山麓と 比べて高温な地下水が存在することが全国各地で 知られている(例えば、高橋、1968; 佐倉、1977、 1978)。このような高温域は、広域地下水流動系 （Tóth、1963）に扔ける流出域にあたることから、 地下深部からの上昇流を仮定すれば、高温異常が 説明できると考えられている。本研究では十勝平 野でも、このモデルが成り立つかどうかについて 検討した。ここで、本研究の場合は他の地域と違っ て浅い高温岩体による寄与の可能性についても併 せて考察を加えた。

資料としては地下水温、地下水位の変動、揚水 試験のデー夕、および水素と酸素の安定同位体比 を用いるとともに、三次元の熱移流拡散シミュ レーションによる解析を行った。

\section{2. 水理地質}

\section{1 水理地質概要}

表 1 に十勝平野の水理地質概要を、また、図 1 に十勝平野中央部 (東西方向) の水理地質構造 (岡、 1984）を示した。十勝平野の水井戸の深度は約 $330 \mathrm{~m}$ 
表 1 十勝平野の水理地質

Table 1 Hydrogeology in the Tokachi plain

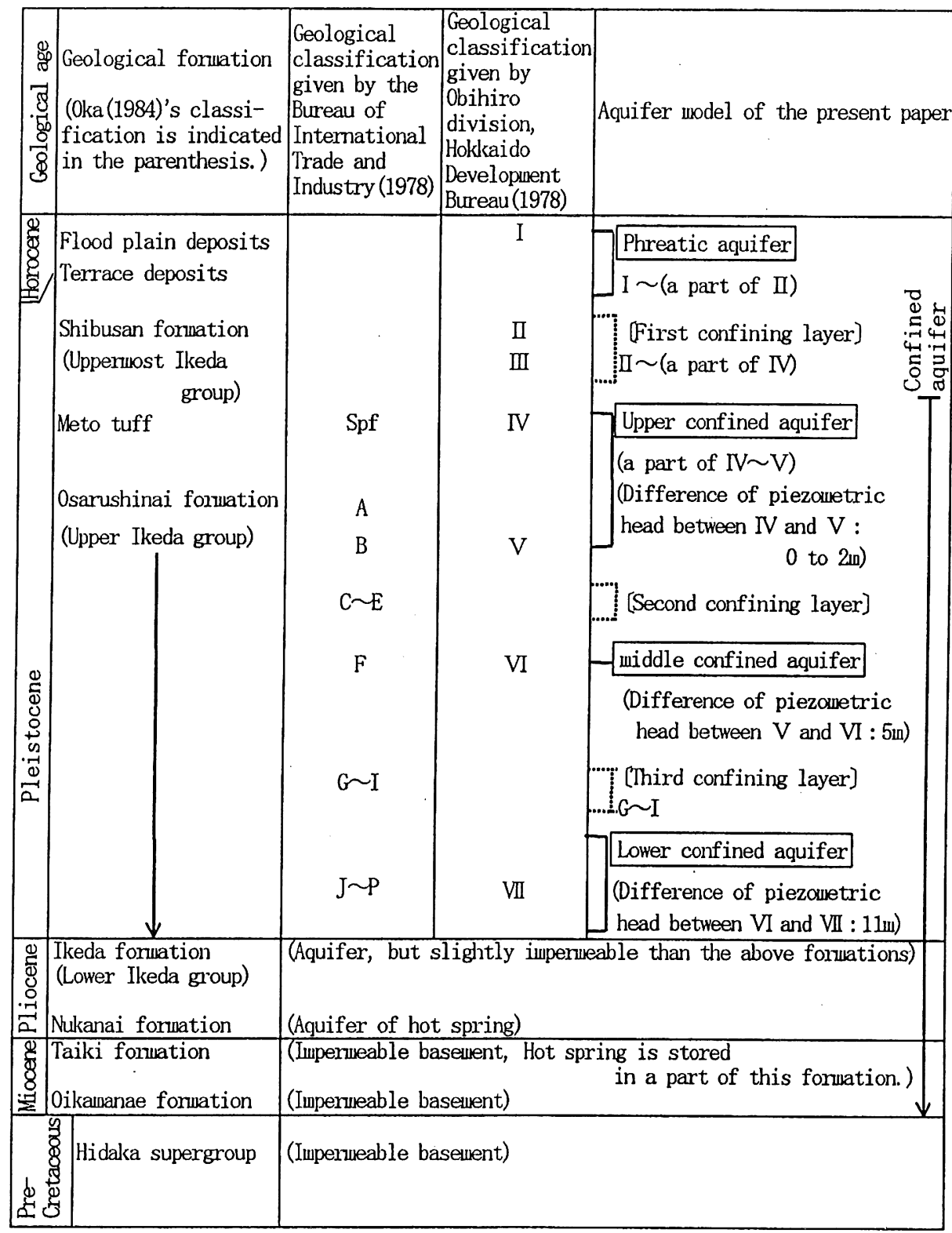

までに分布し、地下水は主に誓流枝内管 (深さ約 $400 \mathrm{~m}$ まで分布) から取水されていることから、図 2 に深さ $300 \mathrm{~m}$ までの南北方向の地質断面図を示 した。

長流枝内層の帯水層区分は表 1 のようにいくつ かの試みがあるが、地下水流動を解鄱するために は区分が細かすぎるので、層別の水頭観測を行っ ている観測井の被圧水頭差を用いて帯水層を 4 層
に再区分した(表1右)。

\section{2 十勝中央断層の東側ブロックの水理地質学 的役割}

地形・地質条件からみて B 級の活断層 (活断層 研究会、1991) である十勝中央断層から東側のブ ロック(十勝川の河谷では中新統以深の地層) は、 十勝平野西部に対して第一近似的に不透水境界的 

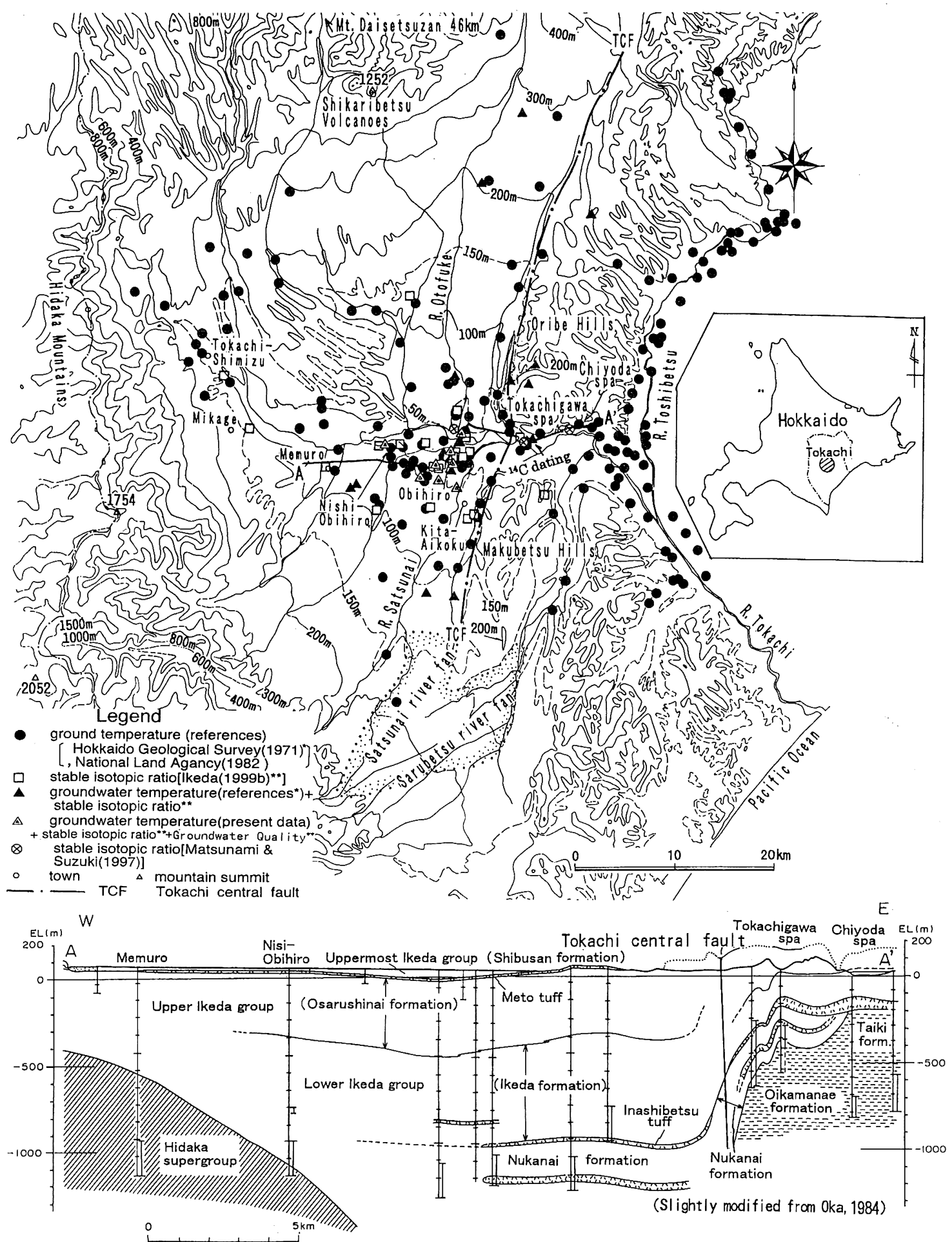

図 1 調査位置図および十勝平野の水理地質断面図

Fig. 1 Location map and hydrogeological cross section of the Tokachi plain 

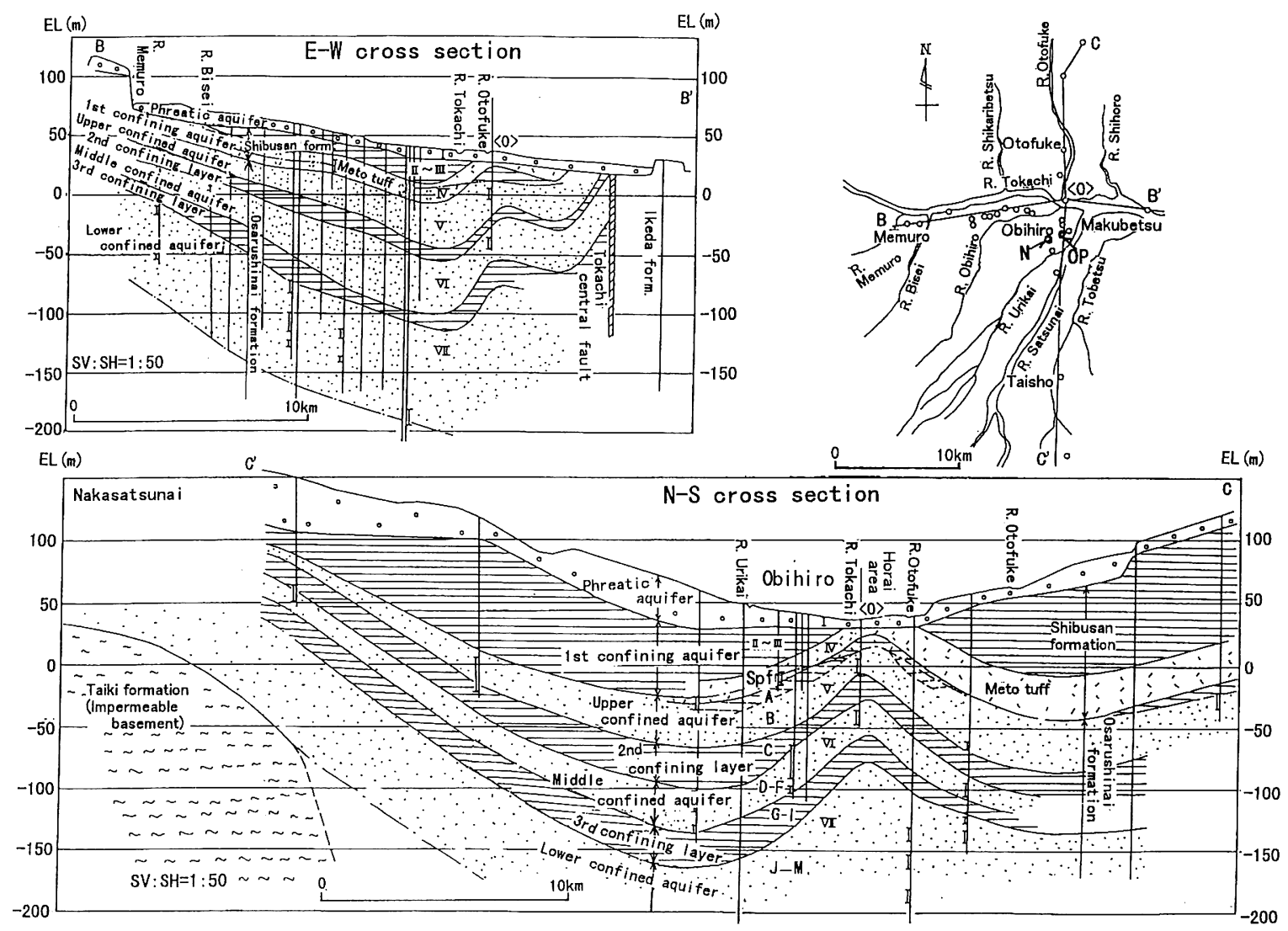

図 2 長流枝内層の水理地質断面図

Fig. 2 Hydrogeological cross section of the Osarushinai forma-

な役割を果たしている可能性がある。以下にこの ことを示唆する水理地質的状況を列举する。以下、 本節では十勝平野の主要部分である十勝平野西部 を西部、十勝中央断層の東側のブロックを東側、 十勝中央断層を単に断層と呼ぶことにする。

(1)地下水位……既存資料における平野西部の長 流枝内層中の地下水位は、西部の地形や地下水面 (概略の形を図13に示す) と相似形である。哚い帯 水層ほど地下水位は高くなっており、地下水流線 は断層と十勝川が交差する付近へ、半円放射状に 集中している。地下水位等高線は断層と直交し、 断層付近の流線は断層とほほ平行である(北海道 開発局带広開発建設部、1999)。流線を横切る流 れはないから、地下水流線は数学的には不透水境界 として扱うことができる(Rushton and Redshaw、 1979）。従って、十勝川の河谷付近を除く断層の 東側ブロックは不透水境界的な役割を果たしてい
る可能性が高い。

(2)地形的理由......東側は西部より標高が最大で 約 $200 \mathrm{~m}$ 高く、十勝川の谷を除いて西部をブロッ クしたような地形となっている(図 1 )。西部の帯 水層面積は約 $1420 \mathrm{~km}^{2}$ あるのに対し、東側の流域 面積は、断層から、十勝川温泉一千代田間を南北 に通る地形流域界までの $212 \mathrm{~km}^{2}$ (西部の $15 \%$ )にす ぎず、涵養される地下水の量は少ない。また、東 側の丘陵群の上部には段丘礫層がのっており、そ の透水係数は地質状況加長流枝内層、池田層の それより数オーダー高いと推定されるものであ り、段丘礫層中の自由地下水の多くは丘陵周辺の 河川へ流出するものと思われる。

(3)地質的理由......西部では深井戸の対象帯水層 である長流枝内層 $\left(\bar{K}=4 \times 10^{-3} \mathrm{~cm} / \mathrm{s}\right)$ が約 $400 \mathrm{~m}$ の 厚さで分布し、断層をへだてて相対的に透水性の 低い東側の池田層 $\left(\bar{K}=2 \times 10^{-3} \sim 1 \times 10^{-4} \mathrm{~cm} / \mathrm{s}\right)$ と 
接する。また、温泉の対象層である西部の糠内層 $\left(\bar{K}=2 \times 10^{-3} \mathrm{~cm} / \mathrm{s}\right)$ は断層をへだてて東側の難透 水層である大樹層や曐花䞇層 $\left(\bar{K}: 10^{-6} \mathrm{~cm} / \mathrm{s}\right.$ オー ダー) と接している。ここで $\bar{K} は$ 北海道開発コンサ ルタント (1999)の揚水試験值や岡 (1990)によった。

(4)地下水水質……西部は中層水型 (炭酸硬度型) が卓越する。すなわち、 $\left(\mathrm{Na}^{+}+\mathrm{K}^{+}\right)$が少なく、 $\mathrm{HCO}_{3}{ }^{-}$が多い。一方、東側は水質が全く異なり、 深層水型(炭酸アルカリ型)または化石水型 (非炭 酸アルカリ型)が卓越し、 $\left(\mathrm{Na}^{+}+\mathrm{K}^{+}\right)$が多くなる （図 3 ：池田ほか、1999b；一部未公表資料(1997 年 8 月採水、試験方法は日本規格協会、1991によ る) ; 道立地下資源調查所、1979、1985から作成)。 (5)基盤岩類までの深度……長周期微動探査(松
島、1989; Matsushima \& Okada、1990)の結果 から、基盤岩 (日高累層群、中新統)までの媣度は 断層を隔てて大きな落差があり、西部では深く、 東側では浅いことが判明している。基盤までの深 度は芽室で $600 \mathrm{~m}$ 、西带広で $1100 \mathrm{~m}$ (以上ボーリン グによる)、帯広では $2100 \mathrm{~m}$ ないし $2400 \mathrm{~m}$ とされ ている。一方、東側では $500 \mathrm{~m}$ (以上長周期微動探 查の $V s=3.2 \mathrm{~km} / \mathrm{s}$ 層まで) となっている。温泉の 帯水層である糠内層では断層を隔てた東西の落差 が800m に達する(図 1)。

以上の状況のみから考えると、十勝中央断層の 東側は、西部に対して難透水性基盤的役割をはた し、その水理条件は不透水境界に近い可能性が高 い。これは断層があることよりもむしろ、十勝川

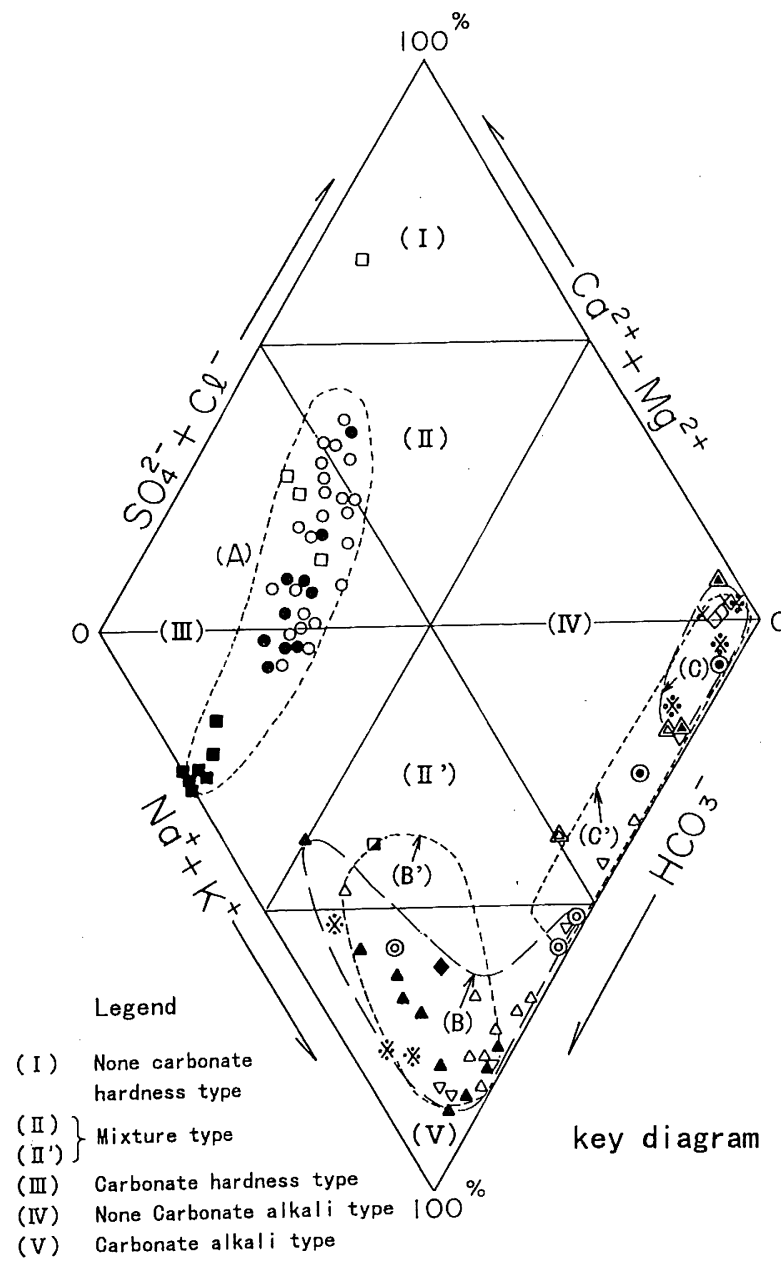

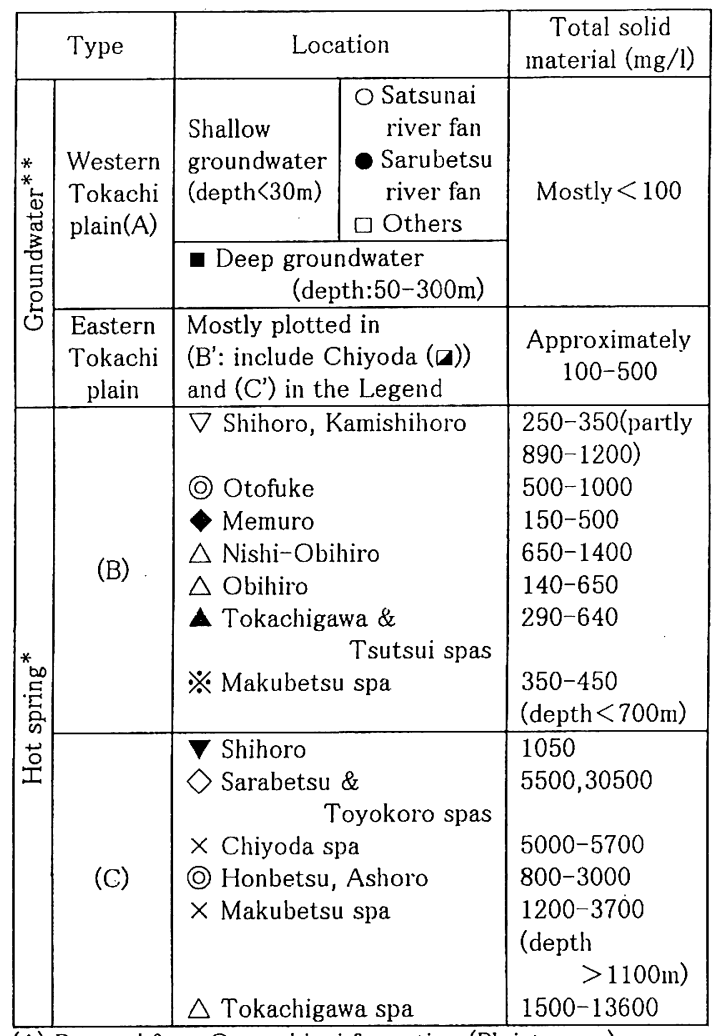
(A) Pumped from Osarushinai formation (Pleistocene)
(B) Pumped from Ikeda and Nukanai formations (Pliocene)
(C) Pumped from Taiki and Oikamanae formations (Miocene)
* Geological Survey of Hokkaido $(1971,1979,1985)$
** O Ikeda et al (1999a), $\square$ - present data

図 3 十勝平野の地下水水質

Fig. 3 Groundwater quality in the Tokachi plain 
付近を除き、比高差 $200 \mathrm{~m}$ で西部より透水性の低 い東側ブロックが立ちふさがっているという、地 形・地質条件によるものであると考えられる。次 節以降では地下水温と安定同位体比等を用いて、 十勝平野西部の地下水流動と東側ブロックの役割 を考察するとともに、本節での考察と整合する結 果が得られるかどうかを議論する。

\section{3. 地下水温}

まず、水井戸の分布する長流枝内層中の地下水 流動を地下水温から推定した。図 4 に、十勝平野 において広域的に得られている地下水温とスク リーン中心深度の関係をプロットした。各地点に おける等温勾配を仮定し、図中の回帰直線の勾配 を用いて様々な深さの水温を $50 \mathrm{~m}$ 深地温(上部被 圧带水層に相当）に換算し、その分布図を図 5 の ように作成した。図 5 から地下水涵養機構につい て次のことが推定される ${ }^{3)}$ 。

(1) $50 \mathrm{~m}$ 深地下水温は日高山脈、北部の火山地带 および帯広から約 $40 \mathrm{~km}$ 離れた南側の分水界に近 づくにつれ低くなり、一部は $9{ }^{\circ} \mathrm{C}$ 以下となってい る。50m 深地下水温は盆地の中央に向かって上昇 し、帯広市中心では $13^{\circ} \mathrm{C}$ 以上となる。地下水温か ら推定される地下水流は、十勝中央断層と十勝川 の交差する付近へ半円放射状に集中している。断 層東側のブロックは $16 \sim 40^{\circ} \mathrm{C}$ 以上の高温域とな り、断層付近で地下水温は大きく変化する。また、 地下水温からみて断層を横切る地下水流は少な く、同断層付近の地下水流線は断層にほぼ平行と 見なせることから、同断層の東側ブロックが不透 水境界的役割をはたしているとの考えは地下水温 からも支持される。

(2)かつて、帯広市の深層熱水は十勝平野北部の 然別火山群で熱せられた地下水が、帯広の地下に 流れ込んだものとの説があったが、地下水温分布 から判断して、深さ約 $250 \mathrm{~m}$ までの带水層への然 別火山群の影響はその周辺に限られ、火山群の南 側で天水により地下水が涵養されている可能性が 高い。深さ千数百 $\mathrm{m}$ までの地温実測值から推定 した北海道の地温構造 (大久保、1998; 大久保ほ か、1998)によれば、東側ブロックは阿寒の延長 方向の高温帯に属し、深さ $20 \mathrm{~km}$ 未満でソリダス温
度以上となるのに対し、西側ブロックは地款内で ソリダス温度に達しないと考えられている。また、 北部の然別火山群を含む大雪山系は高温帯である が、その周辺域を除き十勝平野の西側ブロックの 地下水温にほとんど影響を及ほしていない。以上 から熱水の流入説は考えにくい。

(3)地下水温分布から考えて、深層地下水の涵養 域は盆地の周辺部であり、地下水は盆地中央部で 流出していると推定される。渋山層や長流枝内層 の最媣部は帯広の北 $8 \mathrm{~km}$ 、ブーゲー低重力異常 の中心(岡、1984)や基盤岩の最深部は帯広の北 $20 \mathrm{~km}$ にあり、前者を地下水涵養域と考える向き もあるが、地下水はこれら带水層の低部へ流れる のではなく、地下水温の高温部、すなわち地形の 低部である音更川、札内川、十勝川の合流部へ向 かって流れていると考えられる。このことは地下 水の流れは地質構造のみではなく、地形にも影響 されていることを示唆する。

\section{4. 地下水流速の計算}

\section{1 解析方法}

Tóth (1963)が与えた地下水流動系のモデルに対 して、流出域は定常垂直一次元流、中間域は定常 水平一次元流に単純化し、佐倉 (1978、1984)の解 析法に基づいて熱移流拡散方程式を解いた。

\section{1 .1 モデル 1 地表面に垂直な流れ}

垂直一次元・定常状態の地下水と熱の流れの方 程式は

$$
\frac{\partial^{2} T}{\partial z^{2}}-\frac{C_{w} \rho_{w} v_{z}}{k} \frac{\partial T}{\partial z}=0
$$

で与えられる。ここに、T=温度、 $C_{w} 、 \rho_{w}=$ 地下 水の比熱と密度、 $z=Z$ 座標、 $v_{z}=$ 垂直方向の流速、 $k=$ 熱伝導率である。ただし、 $v_{z}$ は上方に負、下 方に正である。

モデル1a：難透水層の上下面温度が一定の場合 この場合の境界条件は次式で与えられる。

$$
\begin{aligned}
& Z=0 \text { で } T=T_{0} \\
& Z=L \text { で } T=T_{L}
\end{aligned}
$$

ここで、 $T_{0} 、 T_{L}$ は上下境界面における温度であ

り、Lはそれらの間隔である。境界条件 (2)、 


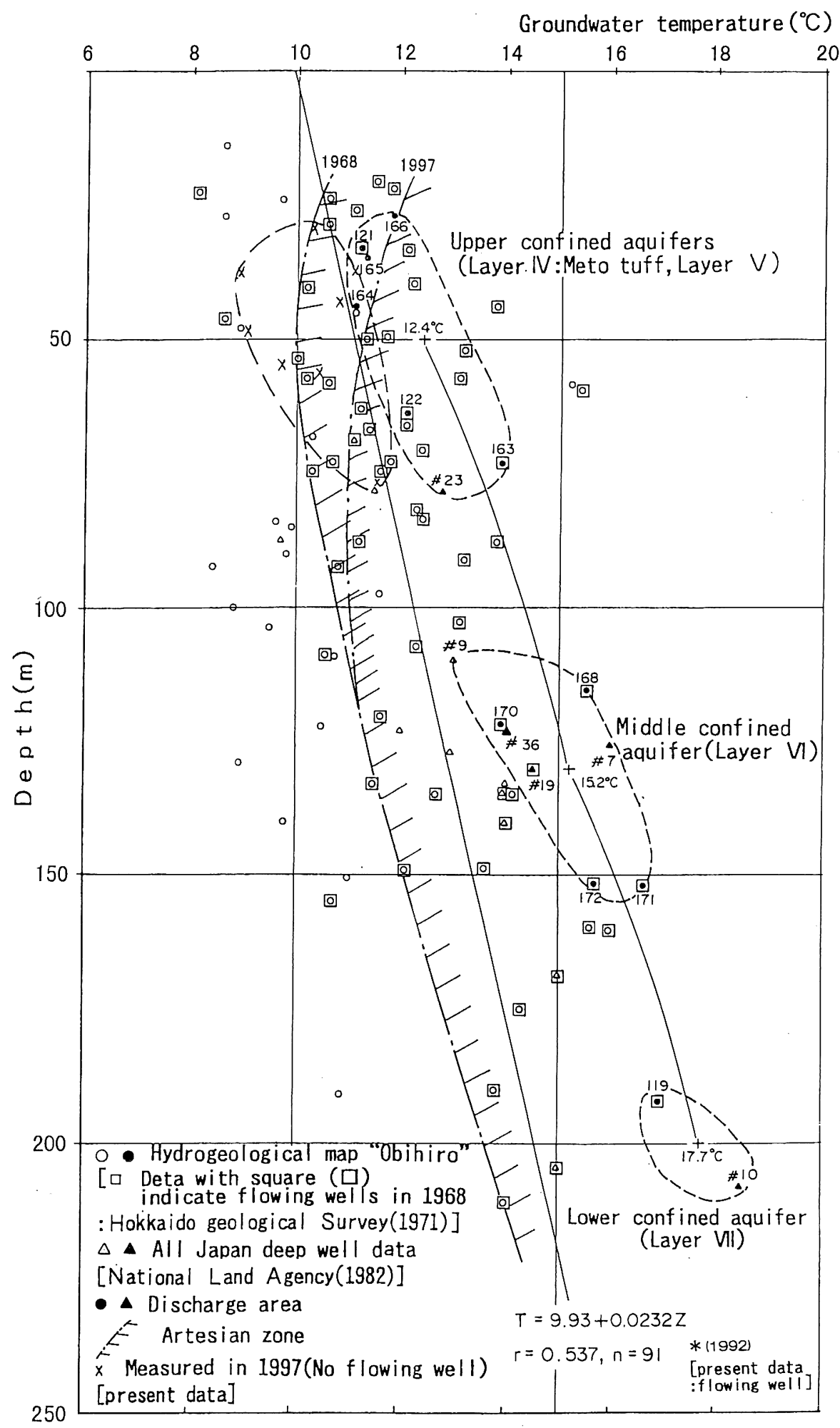

図 4 十勝平野西部における地下水温と深度との関係

Fig. 4 Relationships between groundwater temperature and depth in the western Tokachi plain 


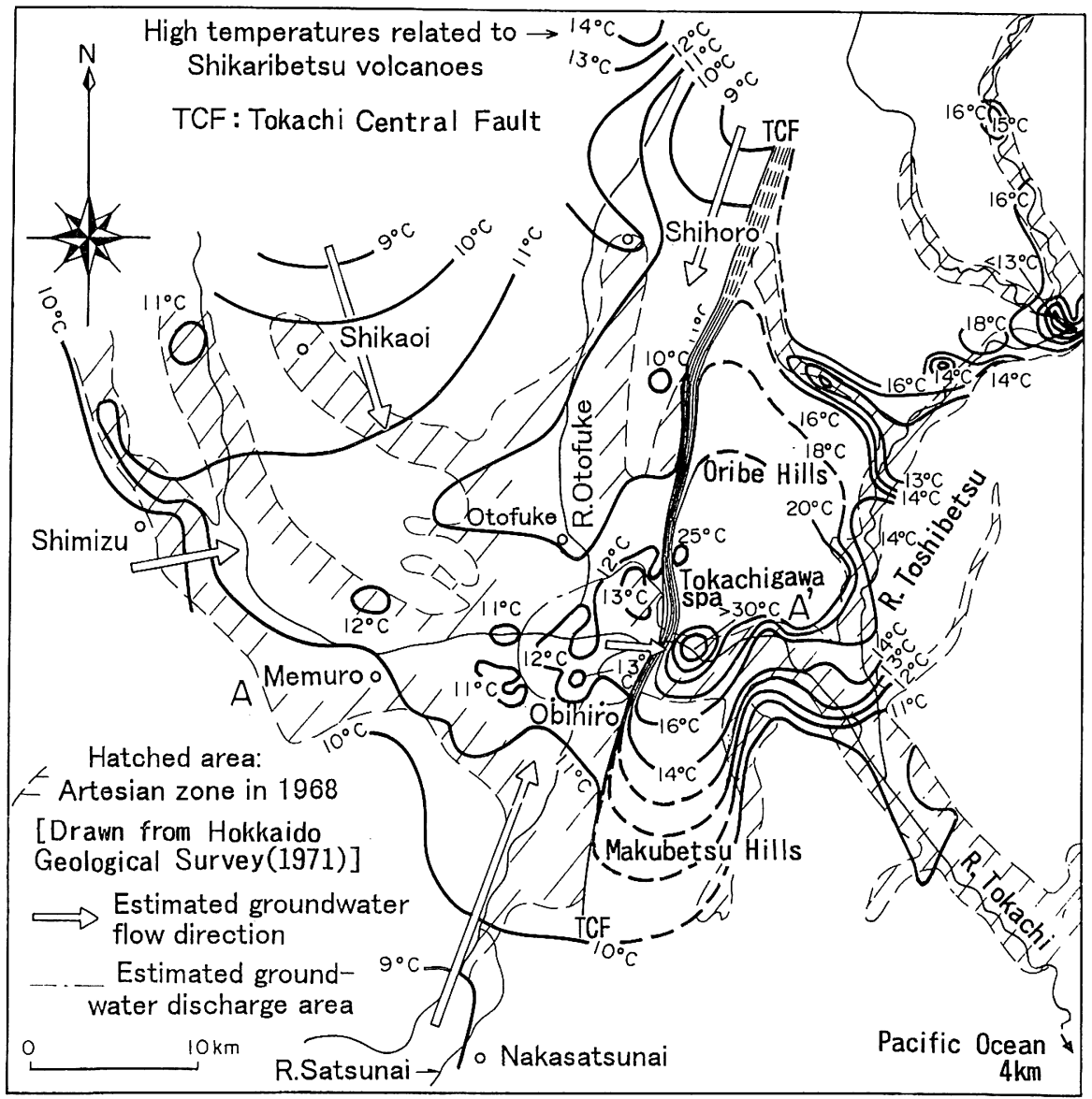

図 5 十勝平野西部の $50 \mathrm{~m}$ 深地下水温分布

Fig. 5 Distribution of $50 \mathrm{~m}$ depth groundwater temperature in the western Tokachi plain

を満足する(1)の解は(4)式となる (Bredehoeft \& Papadopulos、1965)。

$$
\frac{T-T_{0}}{T_{L}-T_{0}}=\frac{e^{\beta z / L}-1}{e^{\beta}-1}
$$

ここで、 $\beta=C_{w} \rho_{w} v_{z} L / k$ である。なお、標準曲線 (図 6) は、(4)式の右辺を横軸、 $Z / L$ を縦軸、 $\beta$ をパラメーターとして作成されている。したがって、 観測值から (4)式の左辺と $Z / L$ をプロットして標 準曲線の中から観測值と一致する $\beta$ を見つけれ ば、地下水の垂直方向の流速 $V z$ を推定すること ができる。

モデル1b：難透水層下面を通る熱流量が一定の 場合

この場合の境界条件は (2)、（5）式で与えられ、
これを満足する(1)式の解は (6) 式で与えられる。 ただし、qは熱流量である。

$$
\begin{aligned}
& Z=L \text { で }-k \frac{\partial T}{\partial z}=q \\
& \frac{\left(T-T_{0}\right) k}{q L}=\frac{e^{-\beta}}{\beta}\left(e^{\beta_{z} / L}-1\right)
\end{aligned}
$$

(6)式も (4)式と同様に標準曲線として表現でき、 $V z$ が推定できる。

\section{1 .2 モデル 2 地表面と平行な流れ}

層厚 $\ell=$ 一定の帯水層中を地下水が一様流速 $V x$ で流れていると仮定すると、伝導による流れ 方向への熱移動は無視でき、定常状態では熱と流 れの方程式は次式となる。

$$
\frac{\partial^{2} T}{\partial z^{2}}-\frac{C_{w} \rho_{w} v_{x}}{k} \frac{\partial T}{\partial x}=0
$$




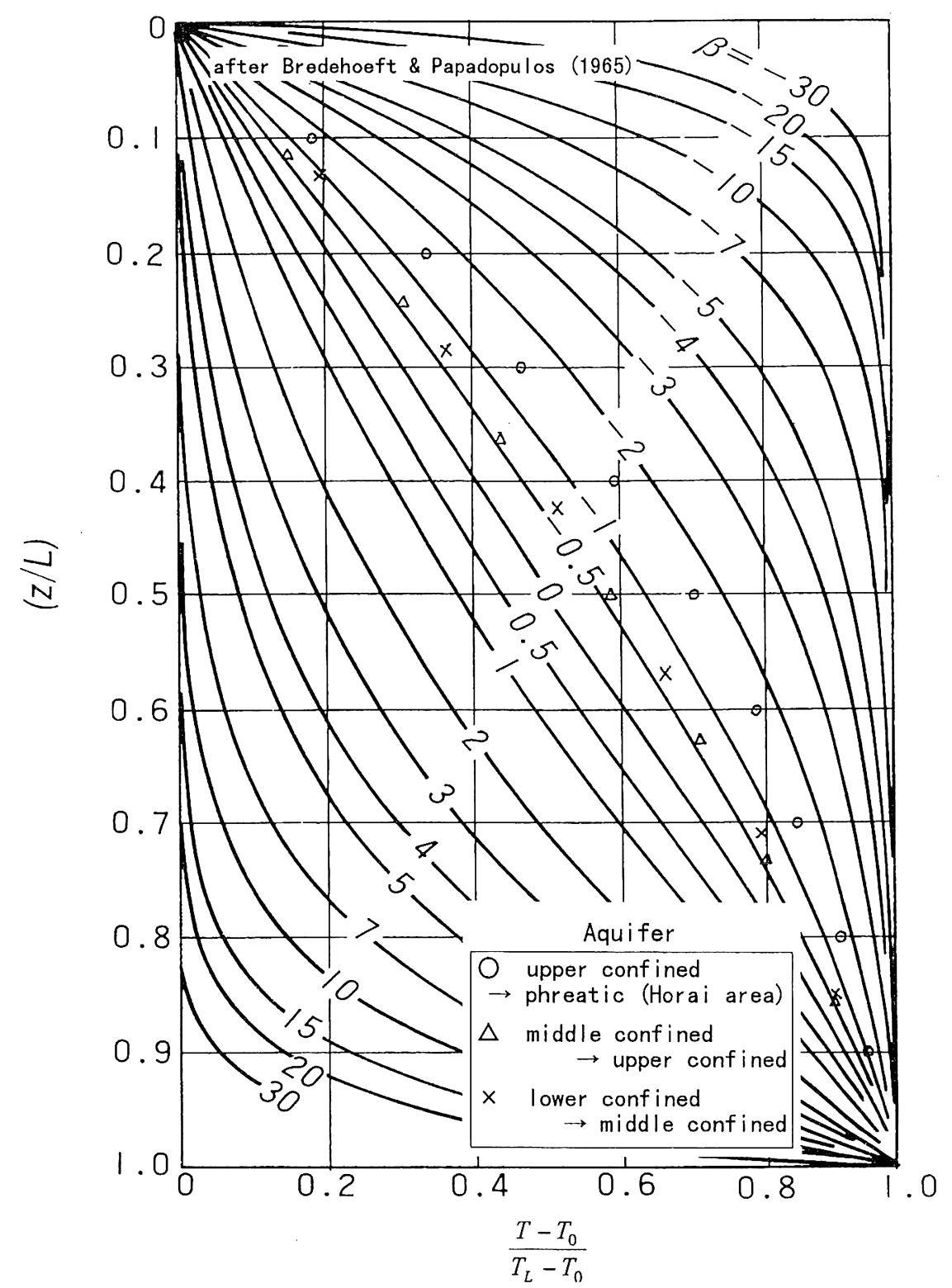

図 6 難透水層中の鉛直一次元地下水温プロファイル（モデル1a）

Fig. 6 Vertical one dimensional temperature profile in an aquiclude (model 1a)

後述 (4.2)するように本調査地では水平流が無 視しえないと考えられるので、帯水層下面を通る 熱流量が一定の場合の解析式を示した。この場合 の境界条件は

$$
\left\{\begin{array}{l}
X=0 \text { で } T=0 \\
Z=0 \text { で }-k \frac{\partial T}{\partial Z}=q \\
Z=\ell \text { で } T=T_{1}
\end{array}\right.
$$

これらを満足する $(7)$ 式の解は (11) 式のようにな る。 
表 2 地下水温から推定した地下水流速

Table 2 Groundwater velocity estimated from groundwater temperature

\begin{tabular}{|l|c|c|c|c|c|c|}
\hline Calculation model & Confined aquifer & $\beta$ & $\begin{array}{c}\text { Darcy } \\
\text { velocity } \\
(\mathrm{cm} / \mathrm{s})\end{array}$ & $\begin{array}{c}\text { Filtration } \\
\text { velocity* } \\
(\mathrm{cm} / \mathrm{s})\end{array}$ & $\begin{array}{c}\text { Hydraulic } \\
\text { gradient }\end{array}$ & $\begin{array}{c}\text { Permeability } \\
\text { of confining } \\
\text { layer(cm/s })\end{array}$ \\
\hline $\begin{array}{l}\text { la (Temperatures } \\
\text { on the upper and } \\
\text { Lower plains of } \\
\text { The aquiclude are } \\
\text { Constant. })\end{array}$ & $\begin{array}{l}\text { upper } \rightarrow \\
\text { phreatic aquifer }\end{array}$ & -1.5 & $\begin{array}{c}(1.1 \sim 2.1) \\
\times 10^{-6}\end{array}$ & $\begin{array}{c}(2.7 \sim 5.3) \\
\times 10^{-6}\end{array}$ & $2 / 33.5$ & $\begin{array}{c}(1.8 \sim 3.5) \\
\times 10^{-5 * * *}\end{array}$ \\
\cline { 2 - 7 } & middle $\rightarrow$ upper & -0.6 & $\begin{array}{c}(1.5 \sim 3.0) \\
\times 10^{-7}\end{array}$ & $\begin{array}{c}(3.8 \sim 7.5) \\
\times 10^{-7}\end{array}$ & $5 / 30$ & $\begin{array}{c}9.0 \times 10^{-7} \sim \\
1.8 \times 10^{-6}\end{array}$ \\
\hline $\begin{array}{l}\text { lo (Heat flow on } \rightarrow \text { middle } \\
\text { the lower plain of } \\
\text { The aquiclude is } \\
\text { constant. }\end{array}$ & -0.7 & $\begin{array}{c}(2.0 \sim 4.0) \\
\times 10^{-7}\end{array}$ & $\begin{array}{c}(5.0 \sim 10) \\
\times 10^{-7}\end{array}$ & $11 / 40$ & $\begin{array}{c}7.2 \times 10^{-7} \sim \\
1.5 \times 10^{-6}\end{array}$ \\
\cline { 2 - 7 } & middle $\rightarrow$ upper & $>-0.35$ & $<1.8 \times 10^{-7}$ & $<6.0 \times 10^{-7}$ & $5 / 30$ & $<1.1 \times 10^{-6}$ \\
\hline 2(Horizontal flow) & Middle & $>-0.35$ & $<2.0 \times 10^{-7}$ & $<6.7 \times 10^{-7}$ & $11 / 40$ & $<3.5 \times 10^{-6}$ \\
\hline
\end{tabular}

Note: The Layer is assumed to be composed of sand and gravel $\left(k=1.67 \mathrm{H} / \mathrm{m} \cdot{ }^{\circ} \mathrm{C}\right.$, porosity $\left.\phi=0.3\right)$ and clayey soil $\left(k=0.84 \mathrm{H} / \mathrm{m} \bullet^{\circ} \mathrm{C}\right.$, porosity $\left.\phi=0.4\right)$ based on Sakura(1978) $\mathrm{s}$ data for Furano and Kamikawa basins.

* Filtration velocity $=$ Darcy velocity / porosity

** Hokkaido Engineering Consul tants Co. Ltd. (1999)

*** Horai area (in the central zone of the Tokachi plain)

$$
\begin{aligned}
& \frac{T_{\Delta V} \cdot k}{q \ell}=\frac{1}{2}+\frac{T_{1} k}{q \ell} \\
& +\frac{2}{\pi^{2}} \sum_{n=1}^{\infty} \frac{1}{2 n-1}\left(\frac{4 T_{1} k(-1)^{n}}{(2 n-1) q \ell}-\frac{8}{(2 n-1)^{2} \pi}\right) \\
& \cdot e^{-\frac{\left(2 n^{2} 1\right\}^{2} \pi p}{4}} \sin \frac{(2 n-1) \pi}{2}
\end{aligned}
$$

ここで $P=k X /\left(C w \rho w V z L^{2}\right) 、 T_{A V}$ は带水層内の 上下方向の平均地下水温である。(11)式から $P$ を パラメーターとした標準曲線が作成されており (佐倉、1978)、熱と水平地下水流の解析を行うこ とができる。なお、モデル1b、2で熱流量は江原・ 横山(1971)、道立地下資源調査所(1995)などから $5.0 \times 10^{-2} \mathrm{~W} / \mathrm{m}^{2}$ をえた。

\section{2 解析結果}

垂直流モデル1a：難透水層の上下面温度を一定 としな場合

標準曲線に図 4 の温度分布をプロットする(図 6)。これから流速を求めると、ダルシー流速と 地下水の循環速度である滤速で $10^{-7} \sim 10^{-6} \mathrm{~cm} / \mathrm{s}$ オーダー、難透水層の透水係数は $7 \times 10^{-7} \sim 4 \times$ $10^{-5} \mathrm{~cm} / \mathrm{s}$ となった(表 2$)$ 。十勝平野の中心 $($ 十勝
川と音更川の合流地点付近)にあり地形的に低い 宝来地区では、上昇流が最も著しく $(\beta=-1.5)$ 、 上部被圧带水層一自由帯水層間の加圧層の透水係 数も大きくなっている。带広市中心部から西へ $4.5 \mathrm{~km}$ の地点で行った揚水試験 (ハンタシュ法)に よれば、上部带水層中の粘性土は $K=9.2 \times 10^{-6} \mathrm{~cm} / \mathrm{s}$ である(北海道開発コンサルタント、1987)。この 粘性土よりも、表 3 で示した難透水層は、上位に あるものは $10^{-5} \mathrm{~cm} / \mathrm{s}$ オーダーとやや $K$ が大きく て圧密が少なく、下位にあるものは、より圧密が 進んでいると考えると揚水試験結果と整合する。

鉛直モデル1b：難透水層下面の熱流量を一定 とした場合

モデル la と同様なので計算結果のみ表 2 に示 す。得られた值はモデル1aの半分以下となり、 熱伝導率 $k=1.2 \mathrm{~W} / \mathrm{m} \cdot{ }^{\circ} \mathrm{C}$ 未満の值を与えると $V z$ は負の值となってしまう。この理由として、鉛直 一次元流を仮定したが、実際には水平流の混合に より熱流量が見かけ上小さめとなっている可能性 がある。しかし、オーダー的にはモデル1a と同 じであり、特別な熱源を考えなくとも大筋では带 広市の深さ約 $300 \mathrm{~m}$ まで地下水温の高温部を一般 
地下水学会誌 第42巻第 1 号 $3 \sim 26$ (2000)

表 3 帯広市街における上部被圧帯水層の帯水層定数とダルシー流速

Table 3 Aquifer constants and Darcy flow velocity of the Upper confined aquifer in Obihiro urban area

\begin{tabular}{|c|c|c|c|c|}
\hline \multirow{2}{*}{$\mathrm{P}_{\text {Item }}^{\begin{array}{c}\text { Calculation } \\
\text { method }\end{array}}$} & \multicolumn{2}{|c|}{ Piezometric head in observation well } & \multirow{2}{*}{$\begin{array}{l}\text { Pumping test } \\
\left(\mathrm{n}=12^{*}\right)\end{array}$} & \multirow{2}{*}{$\begin{array}{l}\text { Groundwater } \\
\text { temperature }\end{array}$} \\
\hline & Weekly change & Daily change & & \\
\hline$T / S\left(\mathrm{~cm}^{2} / \mathrm{s}\right)$ & $2.0 \times 10^{4}$ & $4.4 \sim 8.1 \times 10^{4}$ & $1.8 \times 10^{4}$ & - \\
\hline $\begin{array}{l}\text { Hydraulic conductivity } \\
\qquad K(\mathrm{~cm} / \mathrm{s})\end{array}$ & $\begin{array}{l}6.6 \times 10^{-3} \\
\text { (calculated) }\end{array}$ & $\begin{array}{l}14.5 \sim 26.7 \times 10^{-3} \\
\text { (calculated) }\end{array}$ & $\begin{array}{l}6.0 \times 10^{-3} \\
\text { (observed) }\end{array}$ & - \\
\hline $\begin{array}{c}\text { Darcy flow velocity }(\mathrm{cm} / \mathrm{s} \text { ) } \\
\left.\text { (Hydraulic gradient } \mathrm{i}=4 \times 10^{-3 * *}\right)\end{array}$ & $2.6 \times 10^{-5}$ & $5.8 \sim 10.7 \times 10^{-5}$ & $2.4 \times 10^{-5}$ & $<5.3 \times 10^{-5}$ \\
\hline
\end{tabular}

* $\mathrm{n}$ : the number of the data

**Hokkaido Development Bureau (1999)

的な熱流量で説明できる。

水平流モデル 2 境界条件：難透水層下面の熱 流量 $=$ 一定

資料が比較的そろっている中札内村から帯広市 街部の中部被圧带水層(図 2) について解析する。 モデル 2 の標準曲線は無次元化させたパラメー ターを両軸に用いている。これらのパラメーター を計算し、その交点を結ぶと $P>10$ となる。これ からダルシー流速は $5.3 \times 10^{-5} \mathrm{~cm} / \mathrm{s}$ 以下となった。 中部帯水層の揚水試験值 (データ 7 個)の平均は $K$ $=3.5 \times 10^{-3} \mathrm{~cm} / \mathrm{s}$ であり(北海道開発コンサルタン 卜、1999)、実測動水勾配は $4 \times 10^{-3}$ 程度である (北海道開発局带広開発建設部、1999)からダル シー流速は $1.4 \times 10^{-5} \mathrm{~cm} / \mathrm{s}$ となり、モデル 2 から の推定と整合する(図 7 、表 2 )。

\section{3 被圧水頭の挙動から推定した地下水流速と の比較}

水理学的デー夕から地下水流速を推定し、地下 水温から求めた地下水流速の妥当性を検討した。 带広市中心部の大通公園井 (図 2 の OP 地点。ス クリーン深度49～60m、主に上部被圧帯水層中の 芽登凝灰岩の水頭を示す。)では、日変化として被 圧水頭の極小値は21～22時、極大值は $3 \sim 9$ 時と 15時頃の 2 回現れ、週変化は被圧水頭が月曜日に 最低、木曜日に最高となる(図 8 : 池田、1990)。

これらの変動は昭和54年から現れていることか ら昭和53年頃にさく井され、大通公園井とスクリー ン深度が同程度であり、揚水量が比較的多く、距 離的に近いなどの特徴を持つ特定の井戸が引き起 こしている可能性が強い。また、週変化からみて
揚水量は日曜日に最大、水曜日に最少となる可能 性がある。

帯広市内の321井の検討結果から、上の条件を 全て満たすのは 1 井(図 2 の $\mathrm{N}$ 地点)のみであり、 この井戸が上記の日変化、週変化の主原因と考え られる。感潮井の理論(山本、1983)を用いてこれ らの変化を解析すると、水頭拡散率 $T / S$ は次式 で与えられる。

$$
T / S=(X / t i)^{2} \cdot t_{0} / 4 \pi
$$

ただし、 $T=$ 透水量係数、 $S=$ 貯留係数、 $X=$ 大通 公園井と $\mathrm{N}$ 地点の距離 $(555 \mathrm{~m}) 、 t i=$ 時間の遅れ、 $t_{0}=$ 周期、である。上式で週変化に対し、 $t i=$ 1day、 $t_{0}=7$ days を代入すると、 $T / S=2.0 \times$ $10^{4} \mathrm{~cm}^{2} / \mathrm{s}$ となる。同様に日変化から $T / S=4.4 \sim 8.1$ $\times 10^{4} \mathrm{~cm}^{2} / \mathrm{s}$ を得た。

以上の值と、既存の揚水試験值とを比較する。 上部被圧帯水層の帯水層定数の平均值は透水係数 $K=6.0 \times 10^{-3} \mathrm{~cm} / \mathrm{s} 、 S=3.3 \times 10^{-4}$ 。带広では芽登凝 灰岩中の透水性の高い部分、約 $10 \mathrm{~m}$ にスクリーン を設置している例が多いため、带水層厚を $10 \mathrm{~m}$ と すると揚水試験から推定した值は $T / S=1.8 \times$ $10^{4} \mathrm{~cm}^{2} / \mathrm{s}$ となり、週変化からの推定と同程度に なった。また、表 3 に示したようにダルシー流速 は地下水温から求めた值と水理学的データから求 めた值が互いに整合しており、地下水温から求め た流速は有意であると考えられた。ただし、日変 化データには揚水時刻の変化や地球潮汐の影響な ど種々のノイズが含まれている可能性があり、極 大、極小值の現れる時間がばらつくほか、他の手 法による值より数倍、過大な值となっている。 


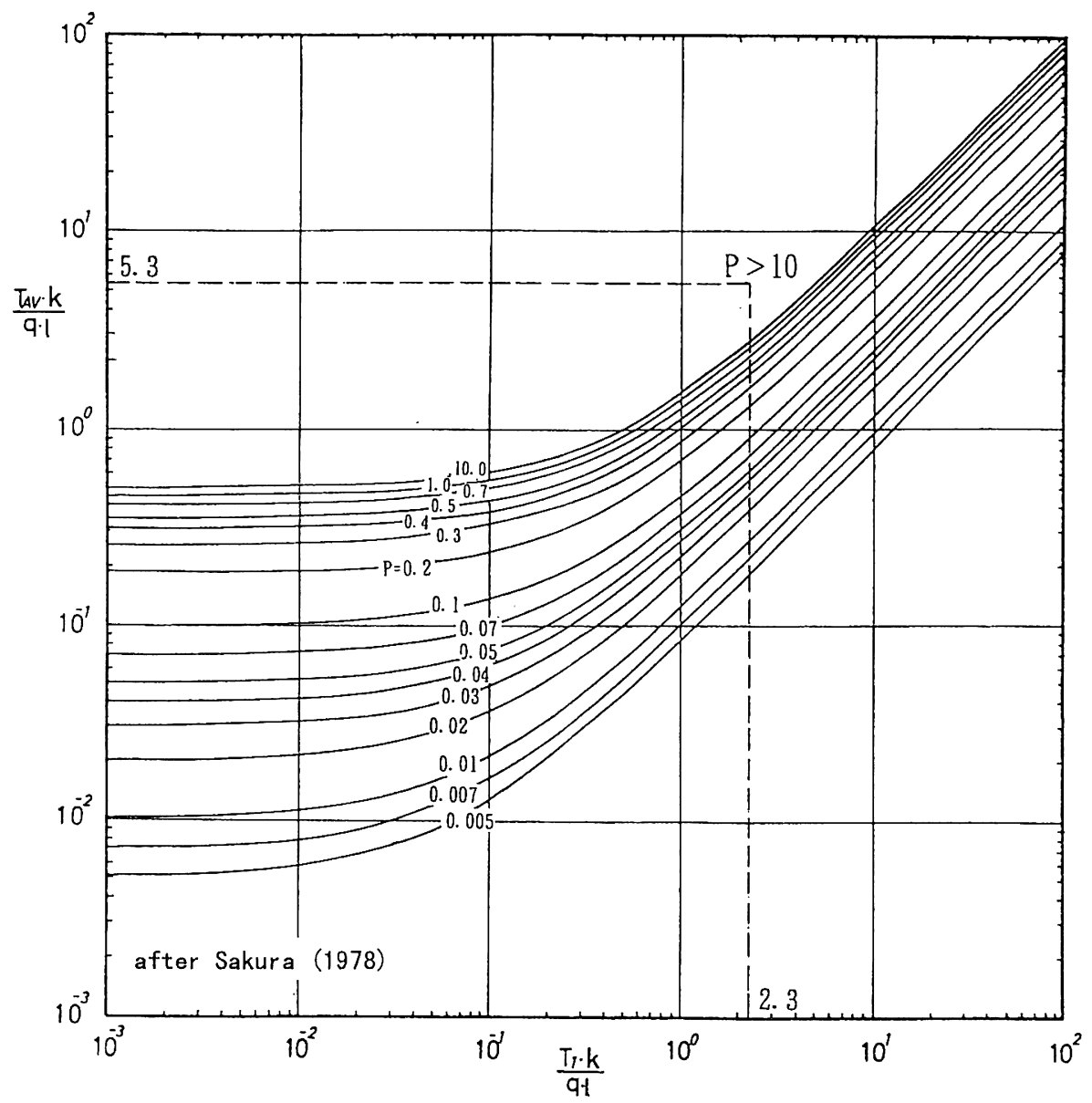

図 7 モデル 2 の標準曲線

Fig. 7 Type curves for Model 2

\section{5. 安定同位体比}

一方、 $\delta \mathrm{D}$ と $\delta^{18} \mathrm{O}$ から十勝平野西部の深層地 下水 (長流枝内層、池田層、糠内層)の地下水流動 を検討した結果、以下のことが明らかになった。 （表 4、図 9〜11; 測定箇所は図 1 に示した。分 析方法、採水時期などデー夕の詳細はそれぞれ池 田ほか、1998；池田、1999b を参照されたい。)

まず、図 9、10に示したように十勝平野の地下 水はすべて天水起源であることが明らかになっ た。以前、漠然と考えられていたような火山起源 の熱水の混入に伴う、高温火山ガスやマグマ水側 への安定同位体比のシフトは認められなかった (図 9)。

深さ50 300m の安定同位体比の平面的分布 (図
11)は地下水温と同様のパターンを示している。 地下水流動系の性質 (Tóth、1963) 加考えて、流 出域に向かうにつれてより古い水、より高所で涵 養された水が出現するはずである。平野の中心部 でも例外的に $\delta \mathrm{D}$ がー78〜 - $80 \%$ を示すものもあ るが、これは上部被圧带水層 (深さ $<70 \mathrm{~m})$ のもの で、近年、地下水位が低下傾向にあるため、より 浅く、より重い地下水が混入している可能性があ る。これらを除くと十勝平野の周辺部では、低地 の降雨により涵養されたと考えられるやや重い地 下水が存在するのに対し、平野の中心に向かうに つれ、より標高の高い所で涵養されたと考えられ る軽い地下水が現れる。十勝清水一御影間にも背 後の日高山脈で涵養されたと思われる軽い地下水 が認められる。これらの軽い水の存在は流出域を 
Groundwater Sun Tue Thu Sat
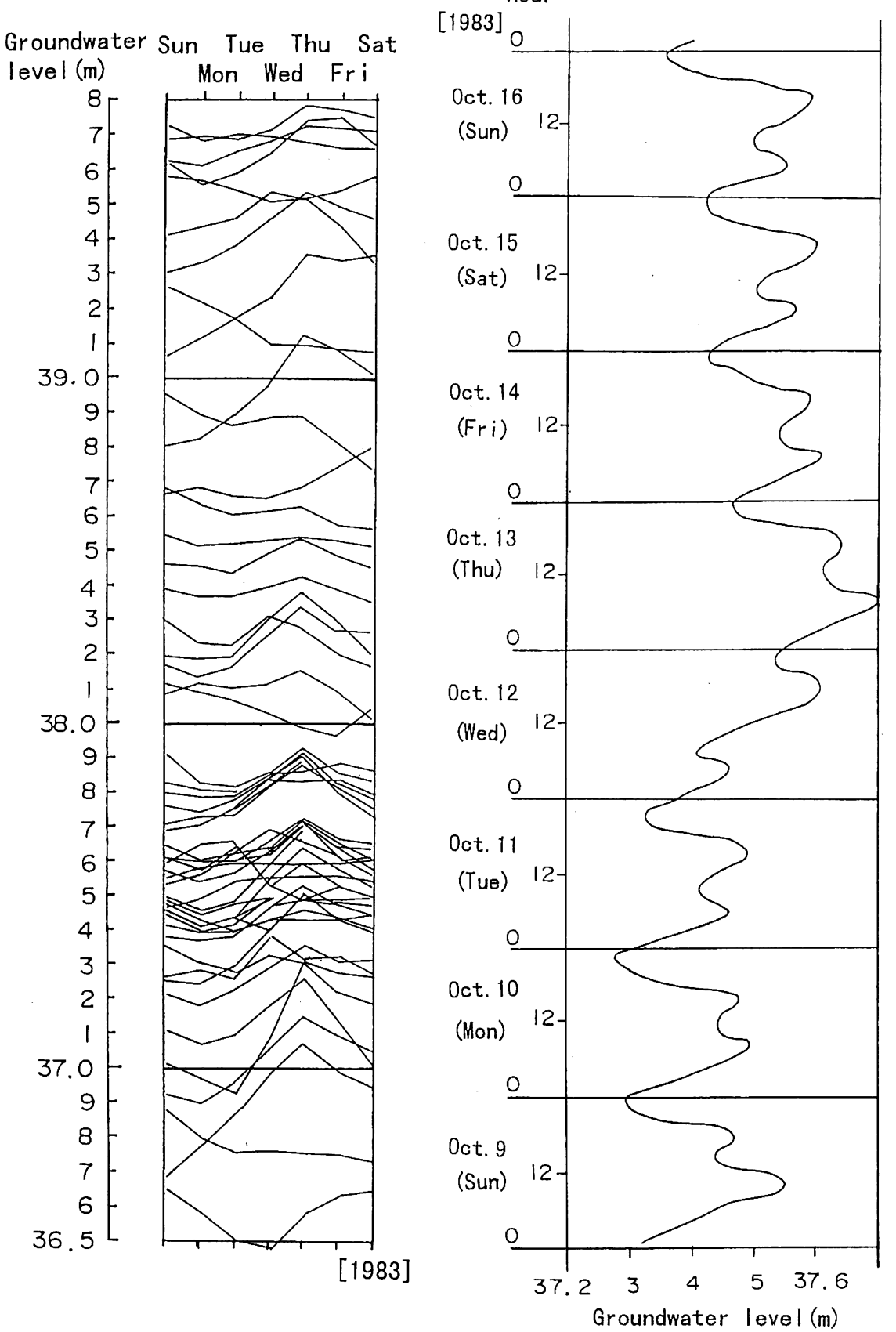

(a) Weekly change

(b) Daily change

图 8 帯広市中心部の地下水位の变化例

Fig. 8 Example of change in groundwater level in the center of Obihiro urban area 
表 4 十勝平野における深層地下水の安定同位体比の平均值

Table 4 Average values of stable isotope ratios in deep groundwater in the Tokachi plain

\begin{tabular}{|l|c|c|c|c|}
\hline \multicolumn{1}{|c|}{ A r e a } & $\begin{array}{c}\delta D \\
(\%)\end{array}$ & \multirow{2}{*}{$\begin{array}{c}\delta^{18} 0 \\
(\%)\end{array}$} & \multicolumn{2}{|c|}{$\begin{array}{r}\text { Estimated altitude of } \\
\text { groundwater recharge } \\
(\mathrm{m})^{* * * *}\end{array}$} \\
\cline { 4 - 5 } & & & $\delta \mathrm{D}$ & $\delta^{18} 0$ \\
\hline $\begin{array}{l}\text { East of the Tokachi } \\
\text { central fault }\end{array}$ & -74.9 & -11.3 & - & 130 \\
\hline The Tokachi river water & -78.7 & -11.0 & 220 & - \\
\hline $\begin{array}{l}\text { Hestern Tokachi plain * (Except } \\
\text { for 0bihiro urban area) }\end{array}$ & -79.4 & -11.7 & 260 & 290 \\
\hline Obihiro urban area & -82.4 & -11.8 & 430 & 330 \\
\hline Tokachi Shimizu to Mikage & -85.5 & -11.8 & 610 & 330 \\
\hline $\begin{array}{l}\text { Hot spring from Nukanai } \\
\text { formation** (P1iocene) }\end{array}$ & -89.5 & -12.9 & 830 & 790 \\
\hline $\begin{array}{l}\text { Hot spring from Miocene time } \\
\text { (0ikamanae formation etc.) }\end{array}$ & -33.3 & -3.9 & - & - \\
\hline
\end{tabular}

* North of the Tokachi river, west of Nishi-0bihiro and south of Kita-Aikoku

** The minimum values: $\delta \mathrm{D}=-97.8 \% 0, \quad \delta^{18} 0=-14.1 \%$

*** Matsunami \& Suzuki (1997)

**** Estimated using the difference from the maximum values ( $\delta \mathrm{D}:-74.9 \%, \quad \delta^{18} 0:-11.0 \%$ )

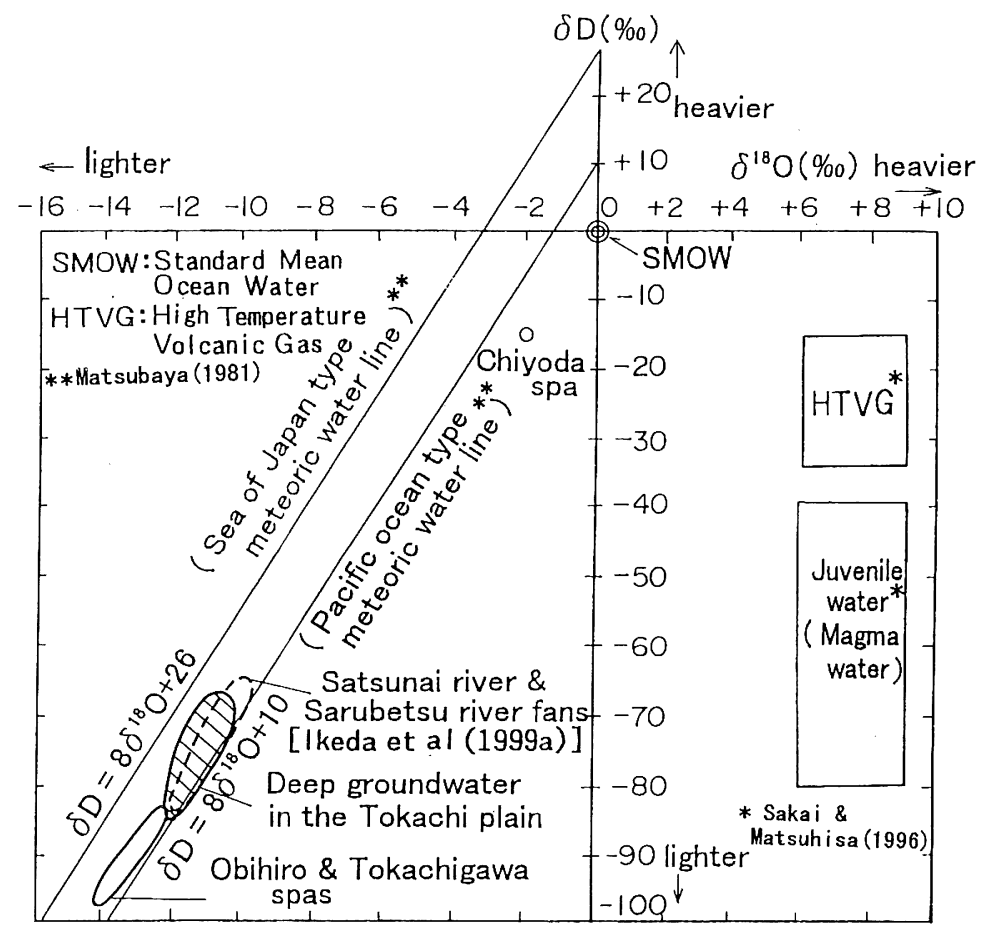

図 9 十勝平野のデルタダイアグラムの模式図

Fig. 9 Schematic of delta diagram of the Tokachi plain 


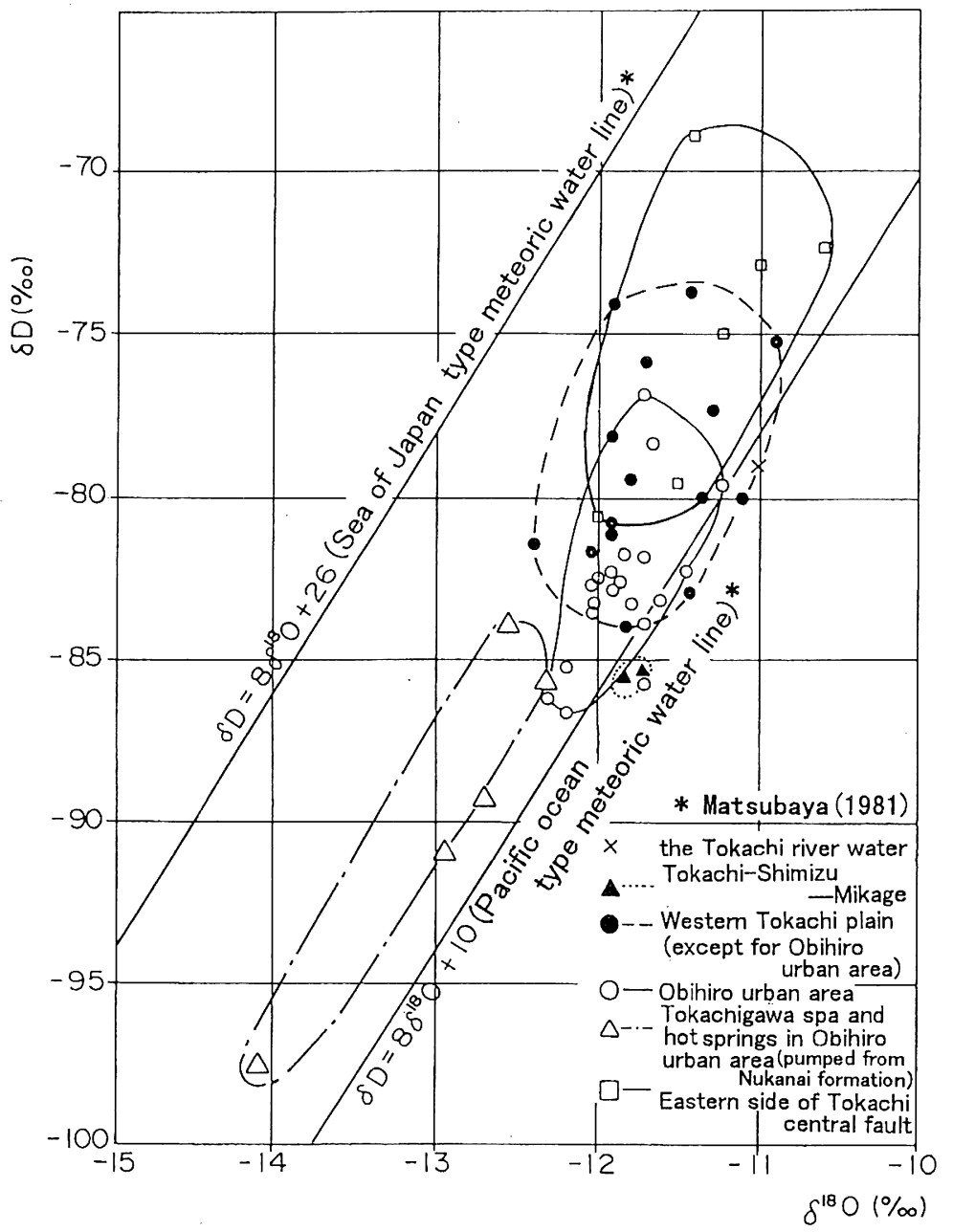

図10十勝平野の深層地下水のデルタダイアグラム

Fig. 10 Delta diagram of the Tokachi plain deep groundwater

示しているものと考えられる。

一方、十勝中央断層の東側では丘陵の上半部を 構成する長流枝内層や、池田層中の地下水の安定 同位体比は西側に比べてやや重く、 $\delta \mathrm{D}$ でー69 - $80 \%$ 程度を示す(図10)。これらは標高30〜 $200 \mathrm{~m}$ の降水や札内川・猿別川扇状地下流の自由 地下水の值がー65〜-70数\%。゙あることから（池 田ほか1999a）、丘陵の降水の影響を受けた、西側 とは起源の異なる地下水と推定される。

十勝川温泉 (糠内層)の同位体比は、 $\delta \mathrm{D} ：-84$ $\sim-98 \%$ 、 $\delta^{18} \mathrm{O}:-12 \sim-14 \%$ と十勝平野で最 も軽い值を示す。糠内層の温泉水の安定同位体比 は酉側ブロックでも同様の值を示しており、十勝 川温泉の水源として西側ブロックの糠内層の温泉
水を考えても矛盾しない。十勝川温泉よりわずか $3 \mathrm{~km}$ 東の千代田温泉 (生花苗層: 新第三紀中新世) の水はかなり重い同位体比 $\left(\delta \mathrm{D}=-15 \%\right.$ 、 $\delta^{18} \mathrm{O}$ $=-2.3 \%$ ：松波・鈴木、1997)を示し、両者に大 きなギャップがある(図 9 )。付近を通る十勝中央 断層の東側ブロックの大樹層、生花苗層は、大部 分、海成で難透水性の堆積岩から構成され(道立 地下資源調査所、1985）、温泉はわずかに狭在す る凝灰質の部分に賦存しており、水理学的にも難 透水層と見なして良いと考えられている(岡、1984)。 長流枝内層(従ってその流出域も)は断層のところ で切れるのに対し、糠内層はこれらの難透水性の 地層に前面を遮られ、断層のところで $800 \mathrm{~m}$ 上昇 して、幅 $4 \mathrm{~km}$ の十勝川の河谷を流出域として糠内 


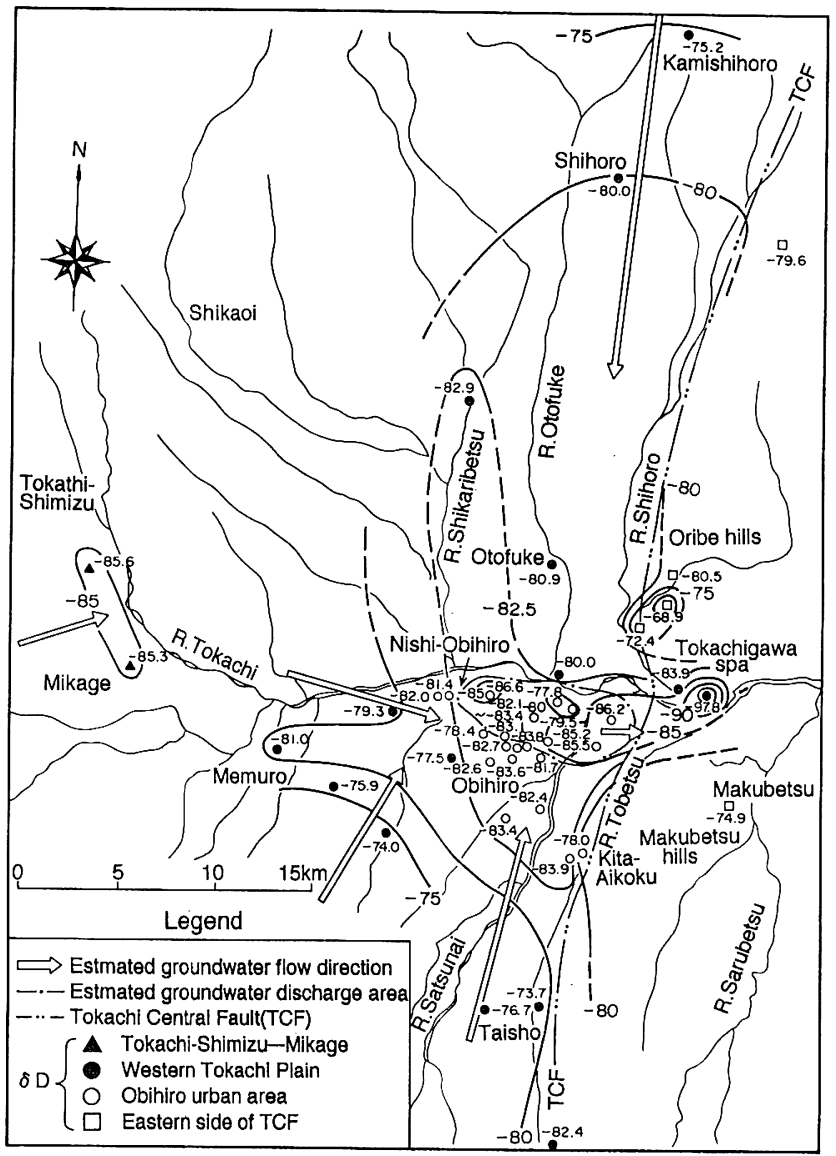

図11十勝平野における深さ50 300mの地下水の $\delta$ D分布図

Fig. $11 \delta D$ distribution of the Tokachi plain groundwater from 50 to $300 \mathrm{~m}$ in depth

層が尖滅する部分に十勝川温泉を形成している (図 1)。すなわち、十勝川の河谷の部分に限ると 十勝中央断層が不透水境界の役割を果たすのは大 樹層以深の地層であって、糠内層とその流出域は 同断層より東へ $3 \mathrm{~km}$ の地点まで伸びている可能 性が高い。

かつて、本論とは別に、大雪山系と日高山脈の 安定同位体比の高度効果を調べ、 $\delta \mathrm{D}:-1.75 \pm$ $0.30 \% / 100 \mathrm{~m} 、 \delta^{18} \mathrm{O}:-0.24 \pm 0.01 \%$ o $/ 100 \mathrm{~m}$ を得 た(池田ほか、1998)。この值を用いると、解析領 域の最低地点 (標高 $20 \mathrm{~m}$ ) からの涵養高度差は十勝 平野西部で $300 \mathrm{~m}$ 弱、帯広市街で $400 \mathrm{~m}$ 弱、带広市 内の温泉と十勝川温泉 (糠内層: 新第三紀鮮新世 から揚湯) で $800 \mathrm{~m}$ に相当する。 $800 \mathrm{~m}$ は大雪山系 や日高山脈など山地部の平均標高にほほ等しく、こ れらの温泉は周辺山地への降水で涵養されたものと
考えられる。最大と最小の同位体比の差は $\delta \mathrm{D}$ ： $-28.9 \%$ 、 $\delta^{18} \mathrm{O}:-3.5 \%$ であり、この全てが高 度効果で説明できるものと仮定した場合には、同 位体比が最小值を示す温泉水は標高 $1500 \mathrm{~m}$ 付近の 降水で涵養されたことになる。

次に軽い安定同位体比を示す地下水が水期に涵 養された可能性があるかどうかについて述べる。 4. で推定した地下水流速を用いると、あくまで も一つの試算にすぎないが、糠内層の地下水では 十勝川温泉の近くまで達するのに 5 千年強、それ から上昇して流出するのに 9 千年強、計 1 万 5 千年 程度を要する。また、長流枝内層では十勝中央断層 付近で流出するのに 6 千年弱と計算された の見積りが正しいものとすると、断層の西側ブ ロックの地下水は温暖期である縄文時代以降に涵 養されたことになる。 
一方、十勝川温泉で最も軽い同位体比を示し、 糠内層で最も古い地下水が存在する可能性のある 地点 (図 1 ) で、加速器質量分析計により温泉水の ${ }^{14} \mathrm{C}$ 年代を調へ(採水1999年 8 月、測定は(株)地球科 学研究所に依頼)、20,000 $1130 \mathrm{yBP}$ を得た。これ はウルム II 氷期の最寒冷期の18,000年前に近い。 しかしながら、糠内層は垔炭を多量に含む層であ るため、dead carbonの影響でかなり古い年代を 示すことが考えられ、十勝川温泉水の実際の年代 はウルム II 水期以降に涵養された可能性がある。

以上から、現時点では長流枝内層の带水層群の 地下水と平野西部の糠内層中の地下水は主に高度 効果によって、また、十勝川温泉の一部ではウル ムII 水期の影響も受けて、軽い值を示しているも のと考えておく。この問題はさらに今後の課題と したい。

\section{6. 熱移流拡散解析}

前節までの考察から、東側ブロック全体の高温 は阿寒の延長である高温岩体に影響されていると しても、十勝川温泉に限ってみると、平野西部の 地下水流と熱が集中して流出している場所である と考えることができそうである。そこで熱と流れ の同時輸送方程式を解く 2 次元および 3 次元の有 限要素法(FEM) プログラムを開発し、3 次元シ ミュレーションを行った(池田ほか、1999c)。こ こではその概要について述べる。

\section{1 数值解析手法}

間隙水の浸透による熱の移流を考慮し、温度を 変数とする土要素における支配方程式をテンソル で表示すると以下のようである。

$$
\begin{aligned}
& \left(K_{i j} h_{, j}\right)_{, i}-q=0 \\
& \rho_{a v} C_{a v} \cdot \dot{T}+\rho_{w} C_{w} v_{i} \cdot T_{, i}-\left(k_{a v i j} \cdot T_{, j}\right)_{, i} \\
& -\psi=0
\end{aligned}
$$

ここで、 $h$ は地下水ポテンシャル、 $K_{i j}$ は透水係数 テンソル、 $q$ は地下水の湧出量、 $T$ は温度、 $\rho_{a v}$ ・ $\rho_{w}$ はそれぞれ土粒子・間隙水混合体と間隙水の 密度、 $C_{a v} \cdot C_{w}$ はそれぞれ混合体と間隙水の比熱、 $\mathrm{v}_{\mathrm{i}}$ は $i$ 方向の浸透流速べクトル、 $k_{a v i j}$ は混合体の 熱伝導率テンソル、 $\psi$ は単位体積当たりの内部発
熱量である。土粒子骨格と間隙水の温度は等しい と仮定し、熱伝導は土粒子骨格と間隙水の熱伝導 率と熱容量を平均化した材質について定式化し た。また、熱移流現象を支配する間隙水の移動は ダルシー則に従うものとした。上記の支配方程式 を離散化して、要素内でマトリックス表示すると 次式となる。

$$
\begin{aligned}
& \int_{V}[B]^{T}[K][B]\{h\} d V=\{q\} \\
& \int_{V}\left\{i \omega \rho_{a v} C_{a v}[N]^{T}[N]+\rho_{w} C_{w}[N]^{T}\{v\}^{T}[B]\right. \\
& \left.+[B]^{T}\left[k_{a v}\right][B]\right\}\{T\} d V=\{\psi\}
\end{aligned}
$$

ここで、iは虚数単位、 $\omega$ は角振動数、 $[N]$ は形 状関数マトリックス、 $[B]$ は形状関数の導関数マ トリックスである。本手法では、まず地下水の定 常流を解析し、ポテンシャルの分布と地下水流速 を求め、それに基づいて周期的变動を伴う温度分 布を解析できるようにしている。しかし、本論に おいては定常的な温度分布のみを対象とした。

\section{2 解析結果}

図12に1985年と1990年の地下水ポテンシャル分 布を示し(糠内層の值は、岡 (1990)のデータから 推定した)、これに基づいてモデルを構築した(図 13、表 5 )。境界条件は、北側と西側がそれぞれ 大雪山麓と日高山脈山麓で带水層が久如する付 近、南側と東側はそれぞれ南側と居辺丘陵の分水 界付近とし、いずれも不透水・断熱境界とした。 上下方向は地下水面および糠内層の最深部付近で それぞれ水頭既知・定温境界、不透水・熱流量一 定 $\left(5.0 \times 10^{-2} \mathrm{~W} / \mathrm{m}^{2}\right)$ 境界とした。

計算結果は次のとおりである(図14(a) (b))。こ こでは図 1、図13と対比するために東西断面のみ を示した。

まず、地下水ポテンシャル分布であるが、1985 年にはすでに揚湯による糠内層中の地下水位の低 下が見られている。図14(a)では、揚湯開始(1973 年頃)以前の地下水位を想定して再現した。この 場合、各層に上下方向と水平方向の異方性を考え ることによって初めて帯水層の下方ほど高くなっ ている実測ポテンシャルが再現できた。この理由 は十勝平野の地層は砂層と難透水性の凝灰岩や亜 炭などの互層なので、上下方向と水平方向の透水 性の異方性が著しいためと思われる。図14(b)の 


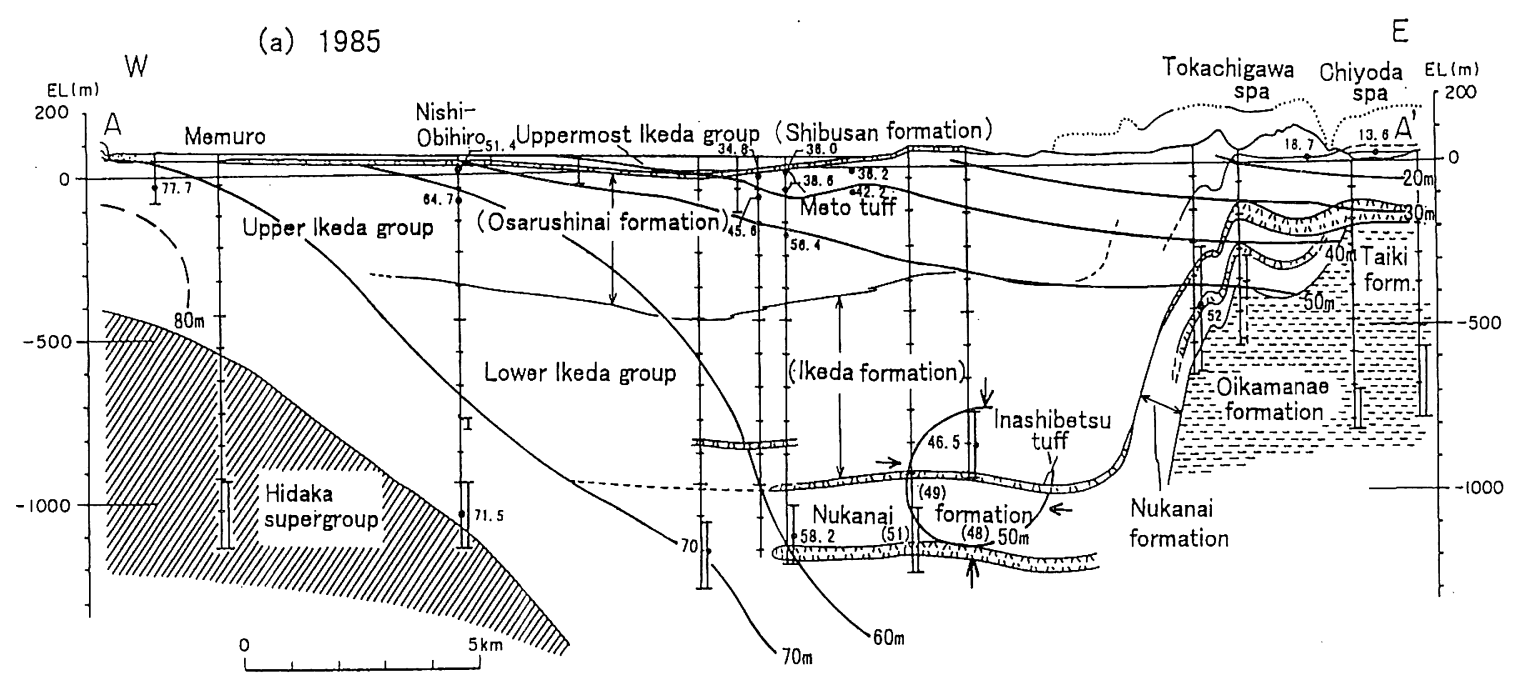

(Geological cross section and potential of the Nulanai formation are based on Oka(1990))

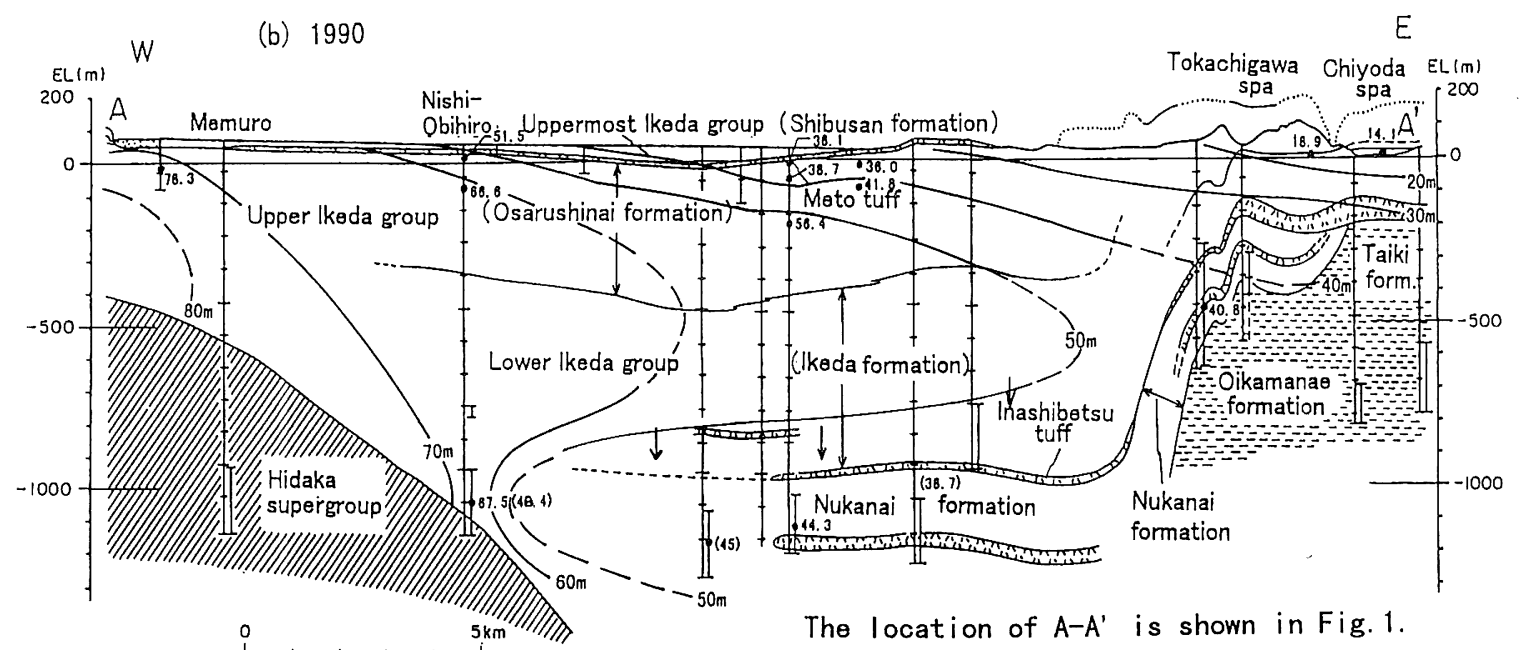

図12十勝平野の深層地下水のポテンシャル図

Fig. 12 Potential map of deep groundwater in the Tokachi plain

地下水温分布から、山麓で涵養された地下水が各 帯水層を通って十勝中央断層付近で収束して流出 している様子がわかる。また、図15の温度検層デー 夕ともおおむね整合していることから、糠内層と 十勝川温泉の温度分布は、従来言われていたよう な特別な熱源を与えなくとも、熱移流で温度上昇 量の多くを説明できることが明らかになった。た だし、十勝川温泉の泉温には1970年代の計測(浦 上ほか、1978)で40ㄷ 以上の部分が $200 \mathrm{~m}$ 以浅まで 分布し、実測值が計算值より $10^{\circ} \mathrm{C}$ 以上高いものも 見られること、また、それらは東側ブロックの熱
流量を 2 倍 $\left(0.1 \mathrm{~W} / \mathrm{m}^{2}\right)$ としたときの温度プロファ イルに近いことから、阿寒の延長である高温岩体 からも熱が供給されている可能性も高い。

近年、帯広市内の温泉㧍よび十勝川温泉では湧 出量が低下している。また、前者では泉温の低下 が著しく、40ㄷ を越える泉源は平成 9 年には 1 井 のみとなった。図12の地下水ポテンシャル分布か ら見て、温泉の帯水層である糠内層の地下水位が 低下することによって、上位の池田層の地下水が 流入し、泉温低下を招いているものと考えられる。 また、これらの結果は十勝平野の地下水や温泉を 


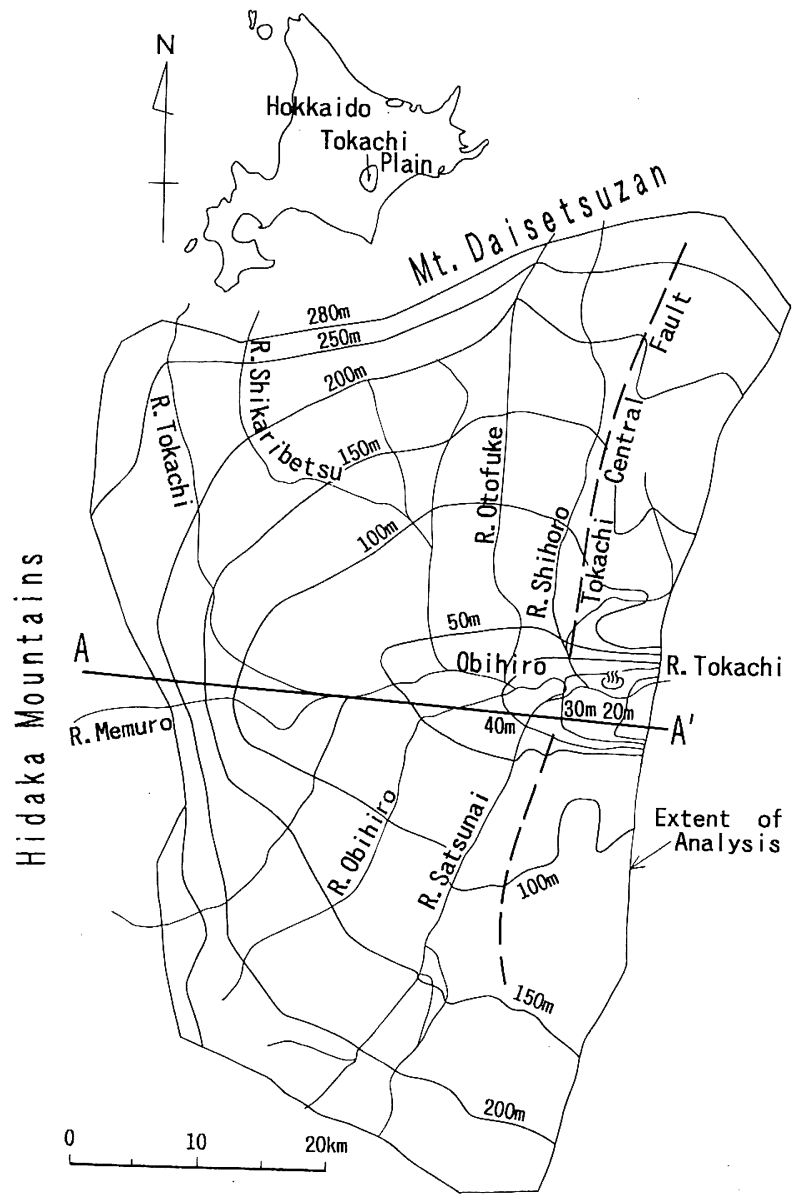

図13熱移流拡散解析で与えた地下水面

Fig. 13 Groundwater table used in thermal advection analysis

表 5 熱移流拡散解析に用いたパラメーター

Table 5 Parameters used in thermal advection-dispersion analysis

\begin{tabular}{|c|c|c|c|c|}
\hline \multicolumn{2}{|c|}{$\begin{array}{l}\text { Geological } \\
\text { forwation }\end{array}$} & $\begin{array}{l}\text { density } \\
\rho_{a v} \times 10^{3} \\
\left(\mathrm{~kg} / \mathrm{m}^{3}\right)\end{array}$ & $\begin{array}{c}\text { horizontal } \\
\text { permeability } \\
K_{h} \\
(\mathrm{~m} / \mathrm{s}) \\
\end{array}$ & $\begin{array}{c}\text { vertical } \\
\text { permeability } \\
K_{v} \\
(\mathrm{~m} / \mathrm{s})\end{array}$ \\
\hline \multicolumn{2}{|c|}{$\begin{array}{l}\text { Shibusan } \\
\text { formation }\end{array}$} & 1.7 & $2.0 \times 10^{-5}$ & $2.0 \times 10^{-8}$ \\
\hline \multicolumn{2}{|c|}{$\begin{array}{c}\text { Osarushinai } \\
\text { formation }\end{array}$} & 1.7 & $2.0 \times 10^{-5}$ & $2.0 \times 10^{-8}$ \\
\hline \multirow{2}{*}{$\begin{array}{c}\text { Ikeda } \\
\text { formation }\end{array}$} & 1 & 1.8 & $1.7 \times 10^{-6}$ & $2.0 \times 10^{-8}$ \\
\hline & 2 & 1.8 & 1. $7 \times 10^{-5}$ & $2.0 \times 10^{-8}$ \\
\hline \multicolumn{2}{|c|}{$\begin{array}{c}\text { Nukanai } \\
\text { formation }\end{array}$} & 1.8 & $5.0 \times 10^{-6}$ & $2.0 \times 10^{-8}$ \\
\hline \multicolumn{2}{|c|}{$\begin{array}{l}\text { Miocene, Pre- } \\
\text { cretaceous }\end{array}$} & 2.0 & $1.0 \times 10^{-8}$ & 1. $0 \times 10^{-8}$ \\
\hline
\end{tabular}

* For specific heat $C_{a v}$ and thermal conductivity $k_{a v}$, $2.0 \times 10^{3} \mathrm{~J} /\left(\mathrm{kg} \cdot{ }^{\circ} \mathrm{C}\right)$ and $1.34 \mathrm{~W} /\left(\mathrm{m} \cdot{ }^{\circ} \mathrm{C}\right)$ are used, respectively based on Junikis (1977). 
(a)

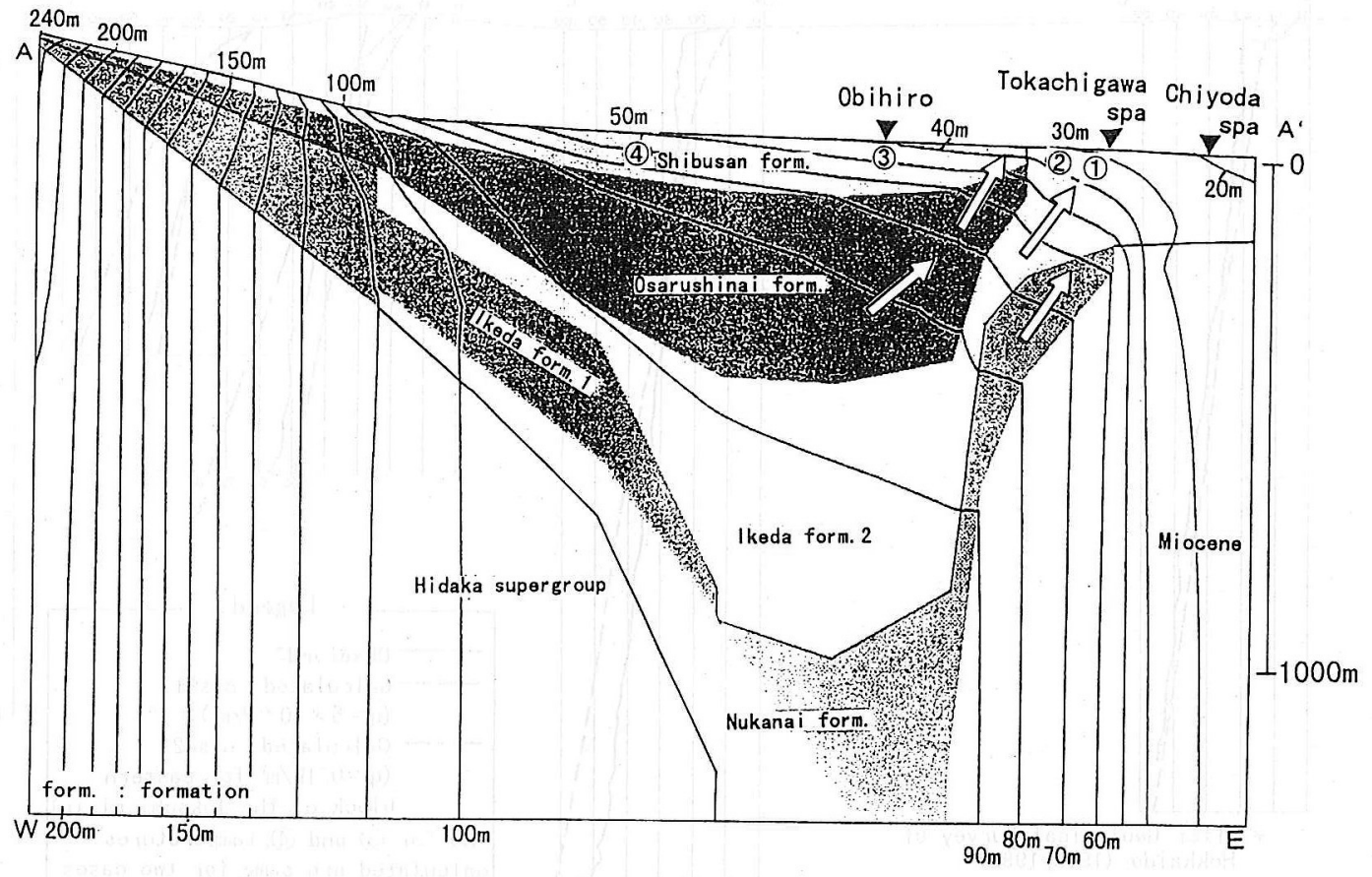

Location of A-A' is shown in Fig. 13.

(1) to (4) indicate the location of numbers in Fig. 16.

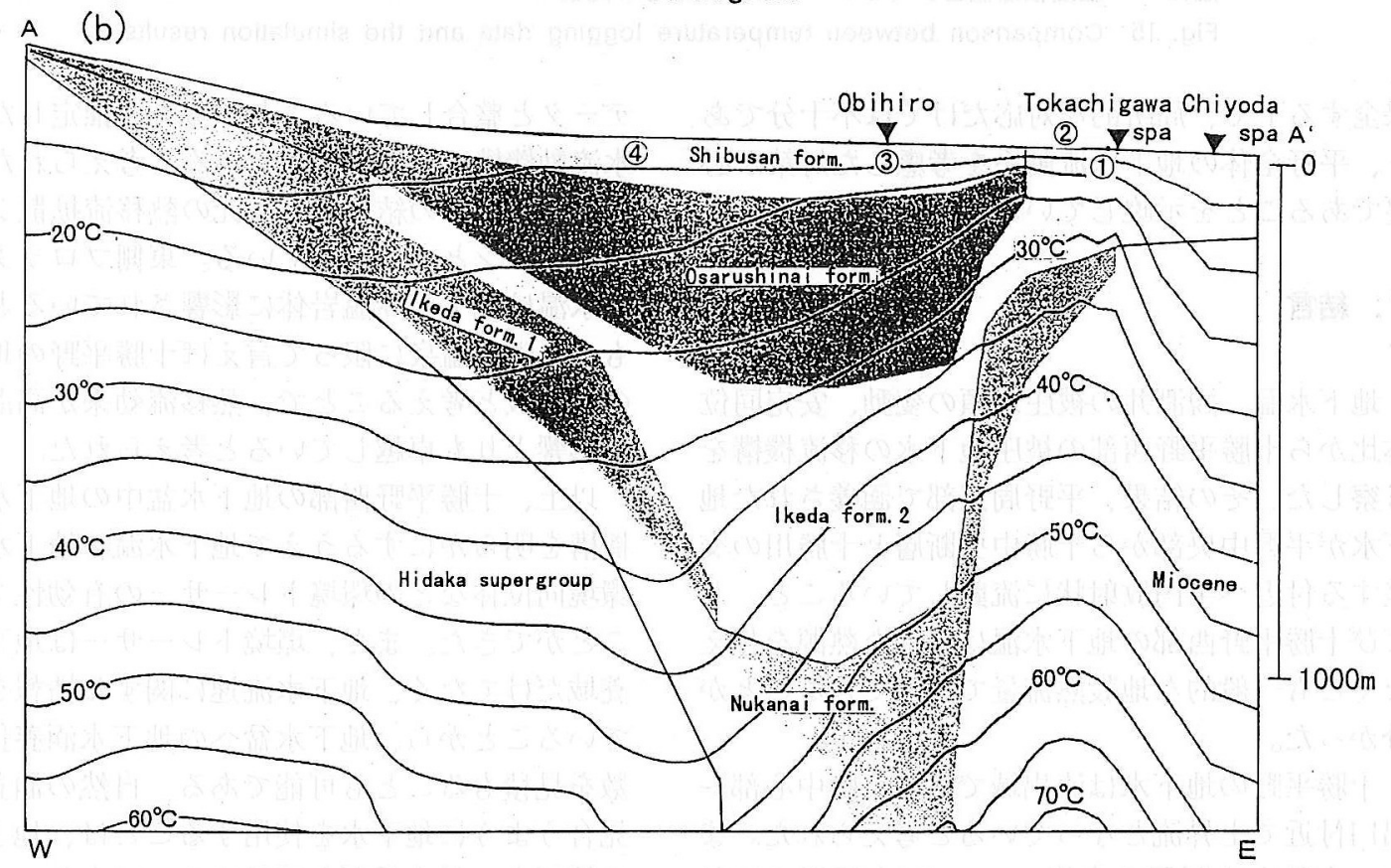

図143 次元熱移流搪散解析結果

(a) ポテンシャル分布 (b) 地下水温分布

Fig. 14 Result of 3-dimentional thermal advection-dispersion analysis

(a) Potential distribution (b) Temperature distribution 


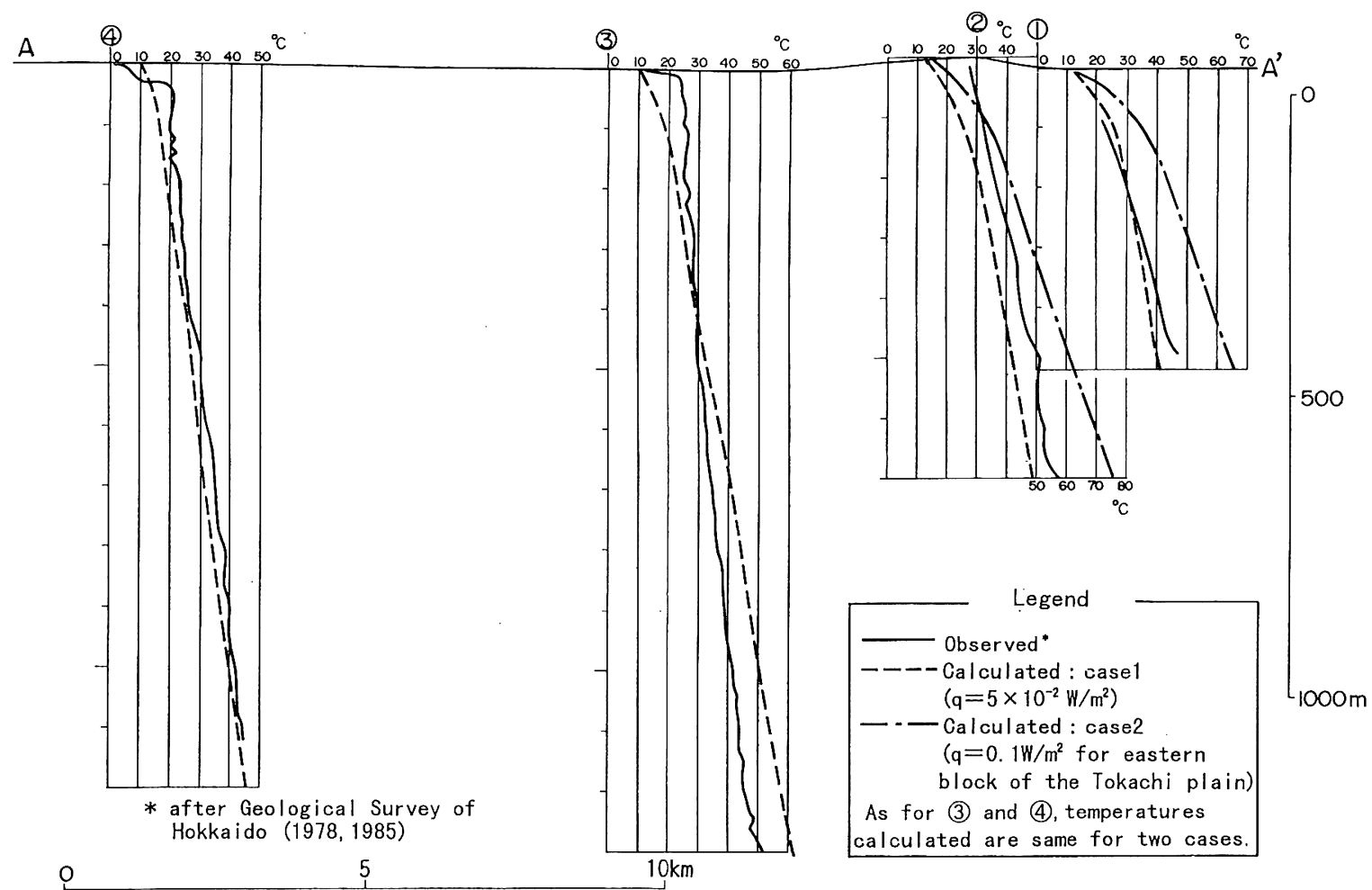

図15温度検層值とシミュレーション結果との比較

Fig. 15 Comparison between temperature logging data and the simulation results

保全する上で、局所的な対応だけでは不十分であ り、平野全体の地下水流動系を考慮した対策が必 要であることを示唆している。

\section{7. 結言}

地下水温、観測井の被圧水頭の変動、安定同位 体比から十勝平野西部の被圧地下水の移流機構を 考察した。その結果、平野周辺部で涵養された地 下水が平野中央部から十勝中央断層と十勝川の交 差する付近へ半円放射状に流動していること、お よび十勝平野西部の地下水温は特別な熱源を与え なくとも一般的な地殼熱流量で説明できることが 分かった。

十勝平野の地下水は流出域である平野中心部 出口付近で上昇流となっていると考えられた。ま た、十勝中央断層の東側ブロック(十勝川の河谷 では中新統以深)の水理条件は不透水境界に近い と見なされた。地下水温や被圧水頭の変動解析か ら求めた帯水層定数が、揚水試験等の水理学的
データと整合していることからも、推定した地下 水流動機構は確かなものであると考えられた。さ らに、これらの結果は 3 次元の熱移流拡散シミュ レーションとも整合している。東側ブロックの地 下水温は地下の高温岩体に影響されているとして も、十勝川温泉に限って言えば十勝平野の地下水 の流出域と考えることで、熱移流効果が高温岩体 の影響よりも卓越していると考えられた。

以上、十勝平野西部の地下水盆中の地下水流動 機構を明らかにするうえで地下水温、地下水中の 環境同位体などの環境トレーサーの有効性を示す ことができた。また、環境トレーサーは地下水涵 養域だけでなく、地下水流速に関する情報を含ん でいることから、地下水盆への地下水涵養量の概 数を見積もることも可能である。自然の涵養量に 見合うように地下水を使用することは、地下水盆 の管理上、最も重要な項目の 1 つであり、この点 からも環境トレーサーによる地下水流動機構の把 握が必要となる。今後、さらにデー夕を蓄積し、 解析精度を高めていく必要がある。 


\section{謝辞}

原稿を読んで貴重な御意見を賜った北海道大学 大学院工学研究科地盤工学講座の三浦清一教授に 感謝する次第である。

\section{注}

1)榧根(1994)によれば、環境中で計測することができ、 水循環のトレーサーとなり得る全ての物理量を意味 し、具体的には水に含まれる安定同位体、放射性同 位体、水質、温度などを指している。と定義される。 2) 活断層研究会 (1991)による東居辺、士幌川、途別川 の各断層を総称して、慣用に従って十勝中央断層と 呼ぶことにする。

3）十勝平野西部は自噴防止用の上ぶたを固定した井戸 が多く温度検層が困難なため、図 4、5のデー夕の 多くは掘削当時(1968年頃)の值 (道立地下資源調査 所、1971)を用いた。1997年に筆者が測定した結果と 比べると、上部被圧帯水層では地下水位低下に伴う 自噴停止域の拡大と地下水温の低下 $\left(1{ }^{\circ} \mathrm{C}\right.$ 強 $)$ が認め られる。

4) 糠内層の透水係数は $K_{\mathrm{h}}=2 \times 10^{-3} \mathrm{~cm} / \mathrm{s}$ 程度 (岡、1990) とされている。いま動水勾配を $4 \times 10^{-3}$ 、空隙率を 0.3 とすると、水平方向の濾速は $\mathrm{v}=2.7 \times 10^{-7} \mathrm{~m} / \mathrm{s}=8.4$ $\mathrm{m} / \mathrm{year}$ 。難透水層中の垂直方向に濾速については表 2 のうちの最小の透水係数 $7.2 \times 10^{-7} \mathrm{~cm} / \mathrm{s}$ 、動水勾配 $30 / 400$ (図12)、 $\phi=0.4$ を仮定すると滤速は $1.35 \times$ $10^{-9} \mathrm{~m} / \mathrm{s}=4.3 \times 10^{-2} \mathrm{~m} /$ year。いま山麓加勝川温泉 までの距離を $43 \mathrm{~km}$ 、涵養域は扇状地であり難透水層 は欠如、流出域の深度を $1 \mathrm{~km}$ 、そのうちの $0.4 \mathrm{~km}$ が難 透水層とすると、上記の水平方向の滤速で $44.6 \mathrm{~km}$ 進 むのに 5300 年、垂直方向の濾速で $0.4 \mathrm{~km}$ 進むのに要す る時間は約 9300 年、計14600年と計算され、上昇する のに多くの時間を要する可能性がある。同様にして 長流枝内層では $K_{\mathrm{h}}=4 \times 10^{-3} \mathrm{~cm} / \mathrm{s}$ 、垂直方向の濾速 3.8 $\times 10^{-9} \mathrm{~m} / \mathrm{s}$ 、水平距離 $40 \mathrm{~km}$ 、垂直距離 $0.4 \mathrm{~km}$ を用いると、 中央断層付近で流出するまでに約5700年となる。

\section{参考文献}

池田光良 (1990)：十勝平野西部の地下水流動系に関す る一考察. 北海道応用地学合同研究会論文集、1、22
$-27$.

池田光良・高田 茂・松枝大治(1998)：北海道の環境 水中のトリチウム濃度及び $\delta$ D、 $\delta^{18} \mathrm{O}$ の高度効果 の推定值について. Radioisotopes、47(11)、812 823.

池田光良 - 竹内篤雄 - 三浦均也 - 松枝大治 - 安田 匡 (1999a）: 十勝平野の複合扇状地の地下水流動機構.

応用地質、39(6)、486 499.

池田光良 (1999b)：環境トレーサーによる北海道の地下 水流動系の評価に関する研究、北海道大学 MS、220p. 池田光良 ·操上広志 ·三浦均也(1999c)：FEM を用い た地下水流動系における地下水温分布解析、土と基 礎、47(8)、25 28.

浦上晃一・ほか 9 名 (1978)：十勝川温泉の地球物理的

調查. 北海道衛生部薬務課、50p.

江原幸男・横山 泉(1971)：北海道における地款熱流 量の測定(その 2 ). 北大地球物理学研究報告、26、 $69 \sim 84$.

大久保泰邦 (1998)：地凯内温度構造解析. 物理探查学 会編『物理探查ハンドブック』586〜588、627６29. 大久保泰邦 - 秋田藤夫 - 田中明子 (1998)：地温勾配図 作成と地下温度構造を求める試み一北海道の例、日 本地熱学会誌、20(1)、15 29.

岡 孝雄 (1984)：十勝平野中央部の深層熱水. 地下資 源調査所報告、55、33 56.

岡 孝雄 (1990)：十勝平野の温泉開発とその資源管理. 日本応用地質学会平成 2 年度研究発表会講演論文集、 169 172.

活断層研究会 (1991)：『新版 日本の活断層』東京大学 出版会、 $64 \sim 65$.

榧根 勇(1994)：熱帯火山地域に抢ける水循環と水利

用 1 . 熱带地方における環境トレーサーによる水 循環調査手法. 地下水技術、36(5)、1 8.

国土庁 (1982)：全国地下水(深井戸)資料台帳. 643 682.

酒井 均・松久幸敬 (1996)：『安定同位体地球化学』東 大出版会、 $111 \sim 127$.

佐倉保夫(1977)：水温分布から地下水流速を推定する 方法. 水温の研究、121 (2).

佐倉保夫 (1978)：水温による地下水循環の研究. 『日本 の水収支』古今書院、291 303.

佐倉保夫 (1984)：温度による地下水調查法. 地下水学 会誌、126(4)、193１97. 
地下水学会誌 第42巻第 1 号 $3 \sim 26$ (2000)

札幌通商産業局 (1978)：北海道帯広、芽室地区地下水 利用適正化調查報告書 $*$ 、31 92.

高橋 稠(1967)：地下水地域調查にみられる水温の総 括的研究. 地質調査所報告、210、1 41.

日本規格協会 (1991)：工業用水試験方法、329p.

北海道開発局带広開発建設部 (1978)：十勝平野地下水 域地下水解析報告書* 、95p.

北海道開発局带広開発建設部治水課 (1999)：十勝平野 の地下水の現況について、地下水技術、41 (7)、4 13.

北海道開発コンサルタント (1987)：昭和62年度十勝川 水系地下水調查解析報告書* $180 \mathrm{p}$.

北海道開発コンサルタント (1999)：平成10年度十勝平 野地下水解析報告書* 、221p.

北海道立地下資源調查所 (1971)：水理地質図幅「帯 広」、48p.

北海道立地下資源調査所 (1979)：北海道の地熱・温泉 (C) 北海道中央部、122 144.

北海道立地下資源調査所 (1985)：北海道の地熱・温泉 -1985年 II 版、10 23.

北海道立地下資源調査所 (1995)：60万分の 1 北海道地 温勾配図.

松島 健 (1989)：物理探査学会第80回講演論文集、121 $\sim 124$.
松波武雄・鈴木隆広 (1997)：道内温泉等の水素·酸素 同位体比. 地下資源調査所報告、68、149 152.

松葉谷治(1981)：水素および酸素同位体比からみた温 泉水の起源、温泉科学、31 (3)、47 55.

山本荘毅 (1983)：『新版地下水調査法』古今書院、157 $\sim 158$.

Bredehoeft, J.D. and I.O. Papadopulos (1965): Rates of vertical groundwater movement estimated from earth's thermal profile. Water Resour. Res., 1, 325 $\sim 328$.

Jumikis, A.R. (1977): Thermal Geotechnics, Rutgers University Press, $342 \sim 346$.

Matsushima, T. and Okada, H. (1990): Determination of deep geological structures under urban areas using long-period microtremors. Butsuri-Tansa, 43(1), 21 $\sim 33$.

Rushton, K.R. and Redshaw, S.C. (1979): Seepage and Groundwater Flow, John Wiley \& Sons, 131 133.

Tóth, J. (1963): A theoretical analysis of groundwater flow in small drainage basins. J. Geophys. Res., 68, $4795 \sim 4812$.

*末公表資料

(受付：1999年 5 月10日、受理：2000年 1 月 8 日) 